\title{
Past African dust inputs in the western Mediterranean area controlled by the complex interaction between the Intertropical Convergence Zone, the North Atlantic Oscillation, and total solar irradiance
}

\author{
Pierre Sabatier $^{1}$, Marie Nicolle ${ }^{2}$, Christine Piot ${ }^{3}$, Christophe Colin $^{4}$, Maxime Debret $^{2}$, Didier Swingedouw ${ }^{5}$, \\ Yves Perrette $^{1}$, Marie-Charlotte Bellingery ${ }^{1,3}$, Benjamin Chazeau ${ }^{1,3,6}$, Anne-Lise Develle ${ }^{1}$, Maxime Leblanc ${ }^{4}$, \\ Charlotte Skonieczny $^{4}$, Yoann Copard ${ }^{2}$, Jean-Louis Reyss ${ }^{1}$, Emmanuel Malet ${ }^{1}$, Isabelle Jouffroy-Bapicot ${ }^{7}$, \\ Maëlle Kelner $^{8}$, Jérôme Poulenard ${ }^{1}$, Julien Didier ${ }^{7}$, Fabien Arnaud ${ }^{1}$, and Boris Vannière ${ }^{7}$ \\ ${ }^{1}$ EDYTEM, Université Savoie Mont-Blanc, Université Grenoble Alpes, CNRS, Le Bourget du Lac, France \\ ${ }^{2}$ M2C, Université de Rouen, CNRS, Rouen, France \\ ${ }^{3}$ LCME, Université Savoie Mont-Blanc, Le Bourget du Lac, France \\ ${ }^{4}$ GEOPS, CNRS-Université de Paris-Sud, Université Paris-Saclay, Orsay, France \\ ${ }^{5}$ EPOC, CNRS-Université de Bordeaux, Pessac., France \\ ${ }^{6}$ LCE, Université Aix-Marseille, CNRS, Marseille, France \\ ${ }^{7}$ Chrono-Environnement, Université de Franche-Comté, CNRS, Besançon, France \\ ${ }^{8}$ SPE, Université de Corse Pascale Paoli, CNRS, Campus Grimaldi, BP 52, 20250 Corte, France
}

Correspondence: Pierre Sabatier (pierre.sabatier@univ-savoie.fr)

Received: 29 August 2019 - Discussion started: 30 September 2019

Revised: 10 January 2020 - Accepted: 13 January 2020 - Published: 7 February 2020

\begin{abstract}
North Africa is the largest source of mineral dust on Earth, which has multiple impacts on the climate system; however, our understanding of decadal to centennial changes in African dust emissions over the last few millenniums is limited. Here, we present a high-resolution multiproxy analysis of sediment core from high-elevation Lake Bastani, on the island of Corsica, to reconstruct past African dust inputs to the western Mediterranean area over the last $3150 \mathrm{cal} \mathrm{BP}$. Clay mineralogy with palygorskite and a clay ratio associated with geochemical data allow us to determine that terrigenous fluxes are almost exclusively related to atmospheric dust deposition from the western Sahara and Sahel areas over this period. High-resolution geochemical contents provide a reliable proxy for Saharan dust inputs with long-term (millennial) to short-term (centennial) variations. Millennial variations have been correlated with the long-term southward migration of the Intertropical Convergence Zone (ITCZ), with an increase in dust input since $1070 \mathrm{cal}$ BP. This correlation suggests a strong link with the ITCZ and could reflect the increased availability of dust sources to be mobilized with an
\end{abstract}

increase in wind and a decrease in precipitation over western and North Africa. For centennial to decadal variations, wavelet analyses show that since $1070 \mathrm{cal}$ BP, the North Atlantic Oscillation (NAO) has been the main climatic forcing, with an increase in Saharan dust input during the positive phase, as suggested by previous studies over the last decades. However, when the ITCZ is in a northern position, before $1070 \mathrm{cal} \mathrm{BP}$, wavelet analyses indicate that total solar irradiance (TSI) is the main forcing factor, with an increase in African dust input during low TSI. With climate reanalysis over the instrumental era, during low TSI we observe a significant negative anomaly in pressure over Africa, which is known to increase the dust transport. These two climatic forcing factors (NAO, TSI) modulate Saharan dust inputs to the Mediterranean area at a centennial timescale through changes in wind and transport pathways. 


\section{Introduction}

The dust cycle is an important part of the Earth system: each year, an estimated $2000 \mathrm{Mt}$ (metric tons) of dust is emitted into the atmosphere (Shao et al., 2011). Mineral dust plays a role in the different components of the climate by affecting the radiative budget and therefore the energy balance of the Earth system. Dust can also act as a cloud condensation nucleus, changing the hydrological cycle by modifying cloud cover and microphysics (Rosenfeld et al., 2008). Mineral dust also contributes to the carbon cycle as an external source of nutrients to the oceans and to remote terrestrial ecosystems (Maher et al., 2010; Pabortsava et al., 2017; Shao et al., 2011; Yu et al., 2015). North Africa is the world's largest source of mineral dust to the Earth system and influences spread over both the Atlantic to the American-Caribbean regions and the Mediterranean to Europe (Goudie and Middleton, 2001; Prospero, 2002). Understanding dust emission, transport, and deposition requires the study of both past and present climatic variations. Advances in remote sensing and modeling have improved understanding of the dust cycle, while improvements in paleo-sciences allow for the reconstruction of both dust record emissions through time and source region fingerprinting (Marx et al., 2018). African dust emissions and transports exhibit variability on diurnal to decadal timescales under different atmospheric patterns (Evan et al., 2016). At the scale of glacial to interglacial climates, dust deposition recorded in marine and continental sediments in middle to high latitudes indicates that dust fluxes have changed greatly over such transitions (Maher et al., 2010). However, except for the African Humid Period (AHP) (deMenocal et al., 2000; Ehrmann et al., 2017; McGee et al., 2013), the influence of the Holocene centennial climate variability on the past dust cycle remains poorly quantified (Cockerton et al., 2014; Mulitza et al., 2010), but it can be a key element of the forcing of climatic variations and therefore deserves to be integrated in transient climate simulations of the Holocene (Albani et al., 2015). For instance, the neglect of atmospheric dust reduction in the early to mid-Holocene in climate models could partly explain the model-data temperature discrepancy in the Northern Hemisphere (Liu et al., 2018).

Past dust deposition in the Atlantic (deMenocal et al., 2000; McGee et al., 2013) and Mediterranean (BoutRoumazeilles et al., 2007, 2013; Ehrmann et al., 2017; Rodrigo-Gámiz et al., 2011; Wu et al., 2017; Zhao et al., 2016) regions is classically reconstructed from marine sediment cores. The respective influence of fluvial versus eolian input and the low time resolution of marine sedimentary records over the Holocene period do not allow for studies of short-term (decadal to centennial) variability. Other continental archives such as peat bogs (Le Roux et al., 2012; Longman et al., 2017) and lakes (Zielhofer et al., 2017) demonstrate the possibility to record African dust. A recent study in the Iberian Peninsula shows the potential for highelevation lake sediment to record African dust (Jiménez-
Espejo et al., 2014), despite the low resolution of the sequence. In this paper, we present a high-resolution African dust record from sediment cores sampled in Lake Bastani, a high-elevation lake (2092 m a.s.l.) located on Corsica in the northwestern Mediterranean Sea (Fig. 1), which records the long-term (millennial) to short-term (centennial) variability of African dust inputs over the late Holocene with high temporal resolution, allowing for the discussion of centennial climate forcing and filling the gap between long-term instrumental observations and millennial reconstructions.

\section{Material and methods}

\subsection{Study area}

In the Mediterranean area, despite a large daily variability, climatological data show a clear seasonal cycle of African dust transport with a maximum during the dry season: transport begins over the eastern basin in the spring and spreads over the western basin in the summer (Moulin et al., 1998). This dust mobilization is strongly related to the presence of low-pressure systems over North Africa (Moulin et al., 1998). Dust deposition in the western Mediterranean region, including the island of Corsica, originates from three main dust emission hot spots called potential source areas (PSAs): PSA1 (northern Sahara), PSA2 (western Sahara), and PSA3 (Sahel) (Prospero, 2002; Scheuvens et al., 2013) (Fig. 1), as demonstrated by deposition collectors associated with satellite observations and back trajectory analysis (Bergametti et al., 1989; Guieu et al., 2002; Vincent et al., 2016) (Fig. 1a).

Lake Bastani (4.2 ha), a high-elevation lake (2092 m a.s.l.) with a maximum depth of $24 \mathrm{~m}$, is located on Corsica in the northwestern Mediterranean Sea (Fig. 1). The Lake Bastani watershed is restricted (17.3 ha) and mainly composed of granodiorite and coarse screes from glacial or rockfall origins, containing no permanent streams and delivering very limited local lithogenic input to the sediments. This lake formed after the last glacial retreat and is delimited northward by glacial deposits. In its southern part a very restricted delta is present and composited by coarse material (coarse sand to gravel).

Three sediment cores referred to as BAS13P1 (IGSN: IEFRA0031; $58 \mathrm{~cm}$ ), BAS13P3 (IGSN: IEFRA0033; $47 \mathrm{~cm}$ ), and BAS13P4 (IGSN: IEFRA0034; $102 \mathrm{~cm}$ ) were sampled in the central part of the lake $\left(42^{\circ} 03^{\prime} 56.65^{\circ} \mathrm{N}, 9^{\circ} 08^{\prime} 02.79^{\circ} \mathrm{E}\right)$ under $21 \mathrm{~m}$ (P4) and $23 \mathrm{~m}$ (P1 and P3) of water depth using a UWITEC gravity corer (Fig. 1b). IGSN has been furnished by the SESAR System (http://www.geosamples. org/, last access: 31 January 2020). All the core metadata are stored in the French Cyber-Core repository (https: //www.cybercarotheque.fr/, last access: 31 January 2020). Core metadata are summarized in Table S1 in the Supplement, and core data are all stored in PANGAEA (https://doi. pangaea.de/10.1594/PANGAEA.910655, last access: 10 January 2020). Samples were also collected in the watershed in 


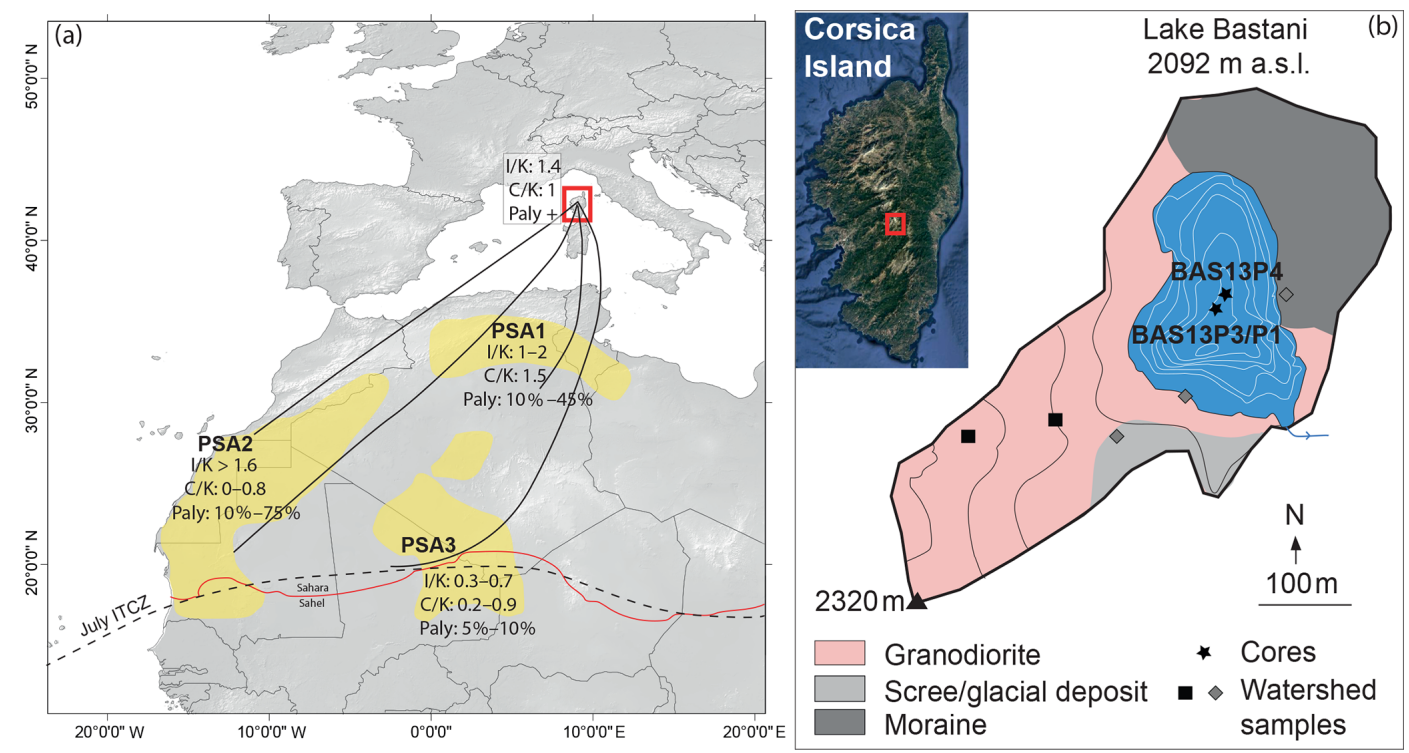

Figure 1. (a) Map of the western Mediterranean area showing major potential source areas for northwestern African dust (PSA1, PSA2, PSA3) with a clay mineral ratio (illite to kaolinite and chlorite to kaolinite) and palygorskite content (Bout-Roumazeilles et al., 2007; Formenti et al., 2011; Scheuvens et al., 2013). Black curves are the main back trajectories for the dust event collected on Corsica (study area, red rectangle); modified from Guieu et al. (2002). The dotted line represents the summer (July) ITCZ position. (b) Aerial photography of Corsica with the localization of Lake Bastani. The Lake Bastani bathymetry map and its watershed with the localization of the three studied cores (BAS13P1, BAS13P3, BAS13P4) and samples on the watershed. In orange is the Sahel-Sahara limit.

different potential sediment sources (granodiorite, moraine, soil, delta; Fig. 1b). These three cores were correlated, and we used data from different sections to have enough material for different analyses.

\subsection{Analytical methods}

Core were split, photographed, and logged in detail, noting all physical sedimentary structures and the vertical succession of facies. The grain size distributions were determined using a Malvern Mastersizer $\mathrm{S}$ at a continuous interval of $1 \mathrm{~cm}$ for core BAS13P4. Ultrasound was applied to minimize particle flocculation. The core was also sampled at $1 \mathrm{~cm}$ steps for core BAS13P4 to obtain the loss on ignition (LOI) following Heiri et al. (2001). LOI550 and LOI950 respectively represent the organic and carbonate content of a sample expressed in percent. LOI at $950{ }^{\circ} \mathrm{C}$ was interpreted to have a carbonate content below $4 \%$ and likely illustrates the uncertainties of this method. The non-carbonate ignition residue (NCIR) was obtained by removing the LOI at $550^{\circ} \mathrm{C}$ from the initial dry weight. Clay minerals were identified by Xray diffraction (XRD) every $2 \mathrm{~cm}$ for core BAS13P4 using a PANalytical diffractometer at the Laboratoire GEOPS (Université de Paris XI) on oriented mounts of non-calcareous clay-sized particles $(<2 \mu \mathrm{m})$. The oriented mounts were obtained following the methods described in detail by Colin et al. (1999). Three XRD trials were performed, each proceeded by air-drying, ethylene glycol solvation for $24 \mathrm{~h}$, and heating at $490^{\circ} \mathrm{C}$ for $2 \mathrm{~h}$. Semiquantitative estimates of clay miner- als were mainly made according to the position of the (001) series of basal reflections on the three XRD diagrams using MacDiff software. Samples were also analyzed by diffuse reflectance Fourier transform infrared spectrometry (FTIRS) using a Thermo Nicolet 380 spectrometer equipped with a liquid-nitrogen-cooled mercury cadmium telluride (MCT) detector and a diffuse reflectance accessory. Each sample was scanned 32 times at a resolution of $2 \mathrm{~cm}^{-1}$ for wavelengths between 4000 and $650 \mathrm{~cm}^{-1}$. The complete absence of the peaks systematically associated with carbonates in lake sediments (1300-1560, 1780-1810, 2460-2640 cm-1) (Rosén et al., 2010) for all the samples indicates that all these sediments are carbonate-free. X-ray fluorescence (XRF) analysis was performed on the surfaces of the split sediment cores at $1 \mathrm{~mm}$ intervals using a nondestructive Avaatech core scanner. The geochemical relative components (intensities), expressed in counts per second, were obtained at various tube settings: $10 \mathrm{kV}$ at $1.5 \mathrm{~mA}$ for $\mathrm{Al}, \mathrm{Si}, \mathrm{S}, \mathrm{K}, \mathrm{Ca}, \mathrm{Ti}, \mathrm{Mn}$, and $\mathrm{Fe} ; 30 \mathrm{kV}$ at $1 \mathrm{~mA}$ for $\mathrm{Cu}, \mathrm{Zn}, \mathrm{Br}, \mathrm{Sr}, \mathrm{Rb}, \mathrm{Zr}$, and $\mathrm{Pb} ; 50 \mathrm{kV}$ at $2 \mathrm{~mA}$ for Ba. Each run lasted 60 s (Richter et al., 2006). Principal component analysis (PCA) was performed using R software. Major and trace element analyses on samples from the watershed $(n=5)$ and lake sediment $(n=10)$ were conducted by flow injection ICP-MS (traces) and ICP-OES (majors) at the Service d'Analyse des Roches et des Minéraux (SARM, Nancy, France) using the method described by Carignan et al. (2001). Each element has a different range of uncertainties, 
with an average of $1 \%-5 \%$ for major elements and $5 \%-$ $10 \%$ for trace elements.

\subsection{Dating}

A continuous sampling step of $5 \mathrm{~mm}$ was applied over the first $10 \mathrm{~cm}$ of BAS13P3 to determine ${ }^{210} \mathrm{~Pb},{ }^{226} \mathrm{Ra}$, and ${ }^{137} \mathrm{Cs}$ activities using well-type germanium detectors placed at the Laboratoire Souterrain de Modane following Reyss et al. (1995). In each sample, the ${ }^{210} \mathrm{~Pb}$ excess activities were calculated by subtracting the ${ }^{226}$ Ra-supported activity from the total ${ }^{210} \mathrm{~Pb}$ activity. Age models are computed with the serac R package (https://github.com/rosalieb/serac, last access: 11 February 2019; Bruel and Sabatier 2020). Five ${ }^{14} \mathrm{C}$ measurements of the terrestrial organic macroremains sampled in core BAS13P1 (four ages) and BAS13P4 (one age) were carried out by an accelerator mass spectrometer (AMS) at the Poznan Radiocarbon Laboratory. The calibration curve IntCal13 (Reimer et al., 2013) was used for the ${ }^{14} \mathrm{C}$ age calibration (Table 1). Then, we used a smooth spline interpolation with the R Code package clam of R software to generate the age model (Blaauw, 2010).

\subsection{Statistical analysis}

Different strategies of multivariate data analysis are used to interpret geochemical data from both sediment core and watershed samples. Principal component analysis (PCA) is performed on major elements as is loss on ignition (LOI) from the BAS13 core and samples from the watershed after "centered log-ratio transformation" (clr transformation; Aitchison et al., 2002). These statistical calculations were conducted with R software using the package "compositions" and allow us to avoid the so-called closure operation on the covariance matrix for major elements (van den Boogaart and TolosanaDelgado, 2008). Classic PCA was conducted on XRF analysis.

The R package "segmented" (Muggeo, 2008) is used for break-point analyses on a given linear regression model to estimate a new model having broken-line relationships with the variables specified. A segmented (or broken-line) relationship is defined by the slope parameters and the break point at which the linear relation changes.

Wavelet analysis (WA) is used to decompose a signal into a sum of small wave functions of a finite length that are highly localized in time for different exploratory scales (Torrence and Compo, 1998). WA corresponds to a band-pass filter that decomposes the signal on the basis of scaled and translated versions of a reference wave function. The Morlet wavelet was chosen as the wavelet reference. Several types of wavelets are available, but the Morlet wavelet offers a good frequency resolution and is used most of the time with a wavenumber of 6 , for which the wavelet scale and Fourier period are approximately equal. All the series were resampled at the initial point number $n$ of the series.
Because WA is sensitive to large, long-term fluctuations that can occur in paleoclimate series, which may mask fluctuations expressed at the highest frequencies, all series were detrended before performing WA. The long-term trends were calculated with autosignal software using a cubic model. The cubic baseline is fitted in a single step matrix solution using a least-squares minimization. The resulting plot of the WA, called the local wavelet spectrum, allows for the description and visualization of the power distribution ( $z$ axis) according to the frequency ( $y$ axis) and time ( $x$ axis). All series were zero-padded to twice the data length to prevent spectral leakages produced by the finite length of the time series. Zeropadding produces edge effects: the lowest frequencies and near the edges of the series are underestimated, and fluctuations that occur in this area must be interpreted with caution. This area is known as the cone of influence. Monte Carlo simulations were used to assess the statistical significance of the detected fluctuations. All the detected fluctuations are statistically tested at the $\alpha=0.05$ significance level against an appropriate background spectrum. Autoregressive modeling was used to determine the autoregressive model (first order: $\mathrm{AR}(1)$ ) stochastic process against which the initial time series was to be tested. For this study, AR(1) corresponds to a red noise of $(\operatorname{AR}(1)>0)$.

Cross wavelet (XWT) and wavelet coherence (WTC) were used to examine the relationship between the dust proxy in the sediment and external forcing. Following Grinsted et al. (2004) this analysis allows for the testing of whether forcing can change over time for specific frequencies. XWT and WTC were calculated using the MATLAB (R2018) wavelet toolbox. To avoid edge effects, time series were downsampled at the closer dyadic size of the shortest time series. As for WA, the Morlet wavelet $(m=6)$ was used because of its compromise between accuracies in both time and frequencies. XWT gives a cross-correlation between the two signals, while WTC provides information about the phase between them. Right and left arrows are respectively in phase or in phase opposition, and up and down arrows respectively show the first or second signal that predates the other one. Dyadic resampling of the time series denoises the signal, allowing us to use a first-order derivative for detrending. Phase arrows were shown for correlation superior to 0.7 .

\subsection{Observation-based data pressure data}

To evaluate the link between solar forcing and changes in wind patterns over the recent period, we used the 20th century reanalysis NOAA (20CR) project version 2 (Compo et al., 2011), consisting of an ensemble of 56 realizations with $2^{\circ} \times 2^{\circ}$ gridded 6-hourly weather data from 1871 to 2010 . Each ensemble member was performed using the NCEP/GFS atmospheric model, prescribing the monthly sea surface temperature and sea ice changes from HadISST as boundary conditions and assimilating sea level pressure data from the International Surface Pressure Databank version 2.0 (https: 
Table 1. List and depth reported in the composite depth of ${ }^{14} \mathrm{C}$ dates for the Lake Bastani cores. The composite depth is obtained from Fig. S2.

\begin{tabular}{|c|c|c|c|c|c|c|}
\hline Samples & $\begin{array}{l}\text { Material } \\
\text { dated }\end{array}$ & Cores & $\begin{array}{r}\text { Composite } \\
\text { depth }(\mathrm{mm})\end{array}$ & $\begin{array}{r}\text { Uncalibrated } \\
\text { age }(\mathrm{BP})\end{array}$ & Uncertainty & $\begin{array}{r}\text { Calibrated age ranges at } 95 \% \\
\text { confidence interval (cal BP) }\end{array}$ \\
\hline Poz-69623 & O. macro & BAS13P1 & 118 & 325 & 30 & $307-468$ \\
\hline Poz-69624 & O. macro & BAS13P1 & 226 & 545 & 30 & 516-635 \\
\hline Poz-73333 & O. macro & BAS13P1 & 380 & 1410 & 30 & $1286-1358$ \\
\hline Poz-69625 & O. macro & BAS13P1 & 566 & 2110 & 30 & 1996-2152 \\
\hline Poz-61153 & O. macro & BAS13P4 & 1020 & 3000 & 35 & $3076-3327$ \\
\hline
\end{tabular}

//rda.ucar.edu/datasets/ds132.0/, last access: 5 April 2018). We used the ensemble mean to perform our analysis. We have computed a linear regression between sea level pressure variations in each grid point and variation of the TSI (Lean, 2009) over the period 1870-2009. We have applied Student's $t$ test to only show the correlation significant at the $95 \%$ level.

\section{Results}

\subsection{Sedimentology and mineralogy}

The sediment consists of olive-gray silty clay with a high organic content $(15.7 \%)$ of up to $20 \%$ over the last few centimeters (Fig. S1 in the Supplement). This increase in organic matter content is related to the lake eutrophication induced by a recent increase in atmospheric nitrogen deposit, which enhances lake primary productivity (Roche and Loÿe-Pilot, 1989). The carbonate content estimated by LOI950 presents a very low value ( $<4 \%$, close to the method uncertainties), and infrared analyses show that there is no carbonate present in this sediment (data not shown). The NCIR is relatively constant and up to $80 \%$, with small variation over the upper $10 \mathrm{~cm}$. This NCIR is mainly composed of biogenic silica (diatom frustules observed in smear slices) and terrigenous input from both the watershed and the eolian flux. The grain size distribution presents a homogenous content (median $(\mathrm{D} 50)=32 \pm 8 \mu \mathrm{m})$ (Fig. S1) mostly affected by biogenic silica not removed before analysis. Grain size in this lake sediment is mostly affected by biogenic silica (diatoms); thus, these data could not be used to track thin particles of eolian origin. We use grain size here to illustrate that there is no coarse deposit link to flood or terrigenous events. However, there is also no large grain size variation related to flood events (Sabatier et al., 2017; Wilhelm et al., 2015); thus, further analyses could not be influenced by grain size variation. On average, the clay mineral fraction is composed of illite $(28 \pm 5 \%)$, smectite $(25 \pm 7 \%)$, kaolinite $(24 \pm 4 \%)$, chlorite $(12 \pm 4 \%)$, and palygorskite $(12 \pm 4 \%)$ and presents large variations (Fig. S1). Toward the top of the core, illite, kaolinite, and chlorite present an increasing trend, with a stabilization for kaolinite around $50 \mathrm{~cm}$, while smectite and palygorskite present a decreasing one. These tendencies are less marked over the upper $50 \mathrm{~cm}$ of the core. All these clay mineral contents present short-term variations at the pluricentimeter scale (Fig. S1).

\subsection{Geochemistry}

The three cores were correlated using XRF data (Fig. S2) to provide enough material for each analysis. Major and trace elements were measured using an XRF core scanner and were subjected to PCA (Fig. S3) to constrain sediment endmembers (Sabatier et al., 2010). Dim1, Dim2, and Dim3 explain $50.5 \%, 14.9 \%$, and $12.1 \%$ of the total observed variance, respectively (Fig. S3). This PCA allows for the identification of three geochemical end-members: (i) Al, K, Fe, $\mathrm{Ti}, \mathrm{Ca}, \mathrm{Rb}, \mathrm{Sr}, \mathrm{Ba}, \mathrm{Zr}$, and (Si), which are related to terrigenous inputs (eolian and/or watershed); (ii) $\mathrm{S}$ and $\mathrm{Br}$, which are linked to the organic matter content (Bajard et al., 2016); and (iii) a $\mathrm{Pb}$ source that may be correlated with periods of past metallurgic activities (Elbaz-Poulichet et al., 2011). We can note that the Si content appeared to be slightly different from other terrigenous elements because $\mathrm{Si}$ is high in aluminosilicate and in diatom content, which is linked to the planktonic productivity in the lake.

Major element concentrations obtained from a quantitative analysis of sediment core and samples from the watershed were subjected to PCA after centered log-ratio transformation (van den Boogaart and Tolosana-Delgado, 2008) (Fig. 2a). Dim1 and Dim2 explain $81 \%$ and $13 \%$ of the total observed variance, respectively, and allow for the identification of two geochemical end-members: (i) $\mathrm{Fe}_{2} \mathrm{O}_{3}, \mathrm{TiO}_{2}$, $\mathrm{MgO}$, and $\mathrm{Fe}_{2} \mathrm{O}_{3}$ correlated with lake sediment samples and (ii) $\mathrm{CaO}, \mathrm{K}_{2} \mathrm{O}, \mathrm{Na}_{2} \mathrm{O}$, and $\mathrm{MnO}$ correlated with samples from the watershed; $\mathrm{SiO}_{2}$ appeared in an intermediate position (Fig. 2a), as for PCA on XRF data (Fig. S3). With this identification of two main end-members, the $\mathrm{Fe} / \mathrm{Ca}$ vs. $\mathrm{Ti} / \mathrm{Ca}$ and $\mathrm{Fe} / \mathrm{K}$ vs. $\mathrm{Ti} / \mathrm{K}$ element ratios from quantitative measurements are then used to understand the geochemical signature of the lake sediment (Fig. 2b). High-resolution XRF Fe content presents (i) a main tendency with an increase between $\sim 40$ and $10 \mathrm{~cm}$ and then a decrease and (ii) shortterm increase in Fe contents at $\sim 8,13,18,25,33,38,45$, $52,59,68,73,85$, and $95 \mathrm{~cm}$ (Fig. 2c). $\mathrm{Fe}_{2} \mathrm{O}_{3}$ concentrations 

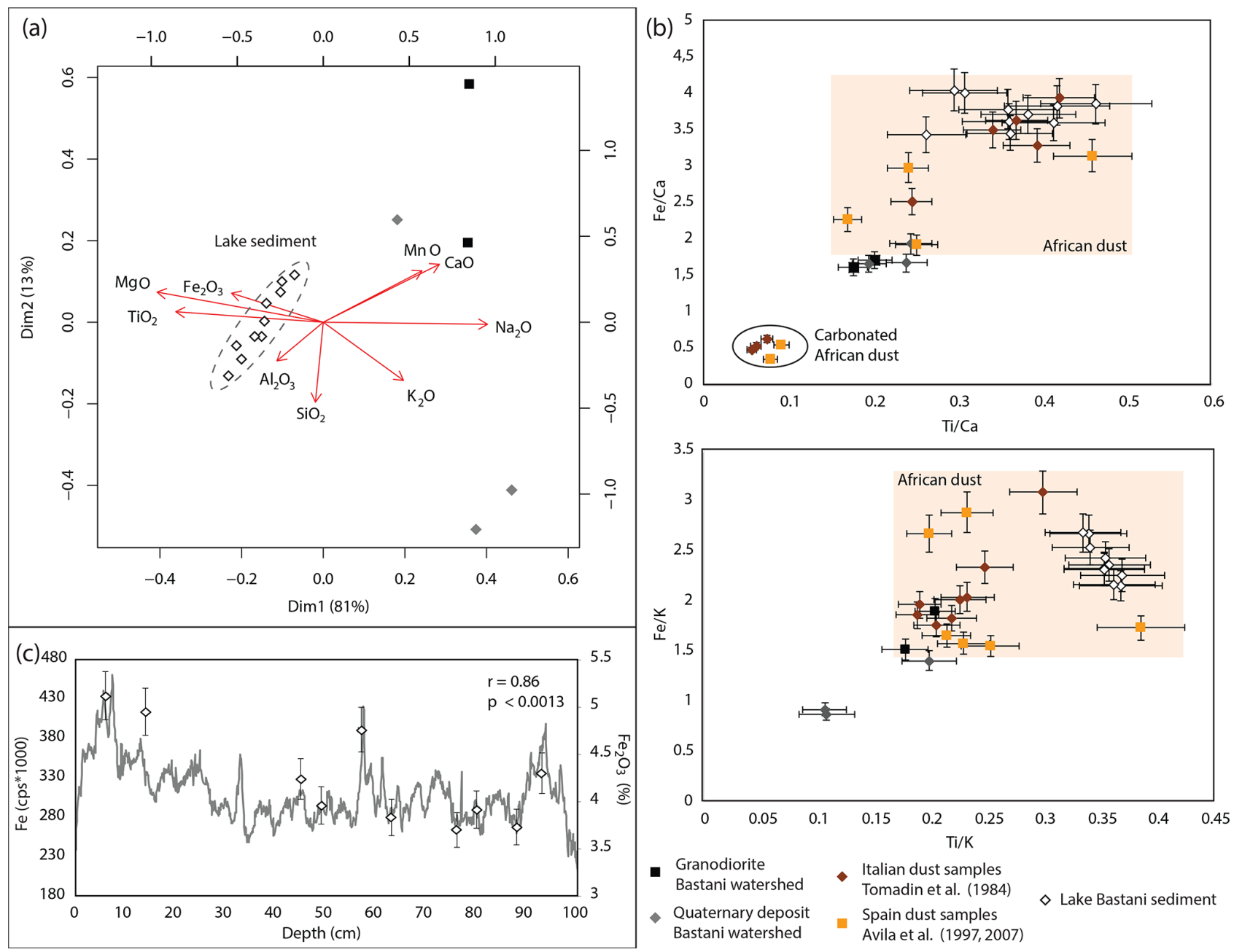

Figure 2. (a) PCA biplot of major elements obtained by ICP-MS measurement corrected for LOI content and after centered log-ratio transformation. Data used in this PCA are from both lake sediment (dotted area) and watershed samples (granodiorite and quaternary deposits). (b) Selected element ratios (Fe/Ca vs. Ti/Ca and $\mathrm{Fe} / \mathrm{K}$ vs. Ti/K) from ICP-MS measurement on lake sediment, watershed samples, and data from dust deposits in the NW Mediterranean (Spain; Avila et al., 1997, 2007) and central Mediterranean areas (Adriatic Sea, Italy, Sicily; Tomadin et al., 1984). Light orange areas correspond to the geochemical signature of African dust from the available dataset. (c) Comparison between Fe content from the XRF core scanner and ICP-MS analyses.

match very well with $\mathrm{Fe}$ contents obtained by the XRF core scanner with the same variations (Fig. 2c), and the correlation between these two types of data $(r=0.86, p<0.0013)$ allows us to use $\mathrm{Fe}$ content from XRF data as a high-resolution quantitative measurement.

\subsection{Chronology}

The excess ${ }^{210} \mathrm{~Pb}$ downcore profile showed a regular decrease punctuated by a phase of homogenized ${ }^{210} \mathrm{Pbex}$ activities (Fig. S4, gray band), which corresponds to the masswasted deposit with a constant Fe content (counts per second - cps) identified in Fig. S2 and to the higher NCIR content (Fig. S1). Following Arnaud et al. (2002) the event was excluded from the construction of an event-free sedi- mentary record because it was considered to be an instantaneous deposit. ${ }^{210} \mathrm{Pbex}$ activities plotted on a logarithmic scale revealed two linear trends providing two mean sedimentation rates of $0.79 \pm 0.1 \mathrm{~mm} \mathrm{yr}^{-1}$ above $3.5 \mathrm{~cm}$ and $0.23 \pm 0.02 \mathrm{~mm} \mathrm{yr}^{-1}$ below $6.5 \mathrm{~cm}$ (Fig. S4). Ages were then calculated using the Constant Flux Constant Sedimentation (CFCS) model applied to the original sediment sequence to provide a continuous age-depth relationship. The ${ }^{137} \mathrm{Cs}$ profile presented one peak at $6.75 \mathrm{~cm}$, which corresponds to maximum nuclear weapon tests in the Northern Hemisphere in 1963 CE. The Chernobyl accident in 1986 CE is not clearly visible on this profile. This age model is confirmed by the correlation between the ${ }^{210} \mathrm{Pbex}$ and the ${ }^{137} \mathrm{Cs}$ peak (Fig. S4).

Sediment core chronology is based on short-lived radionuclide data (Fig. S4) and five radiocarbon dates (Table 1), both 


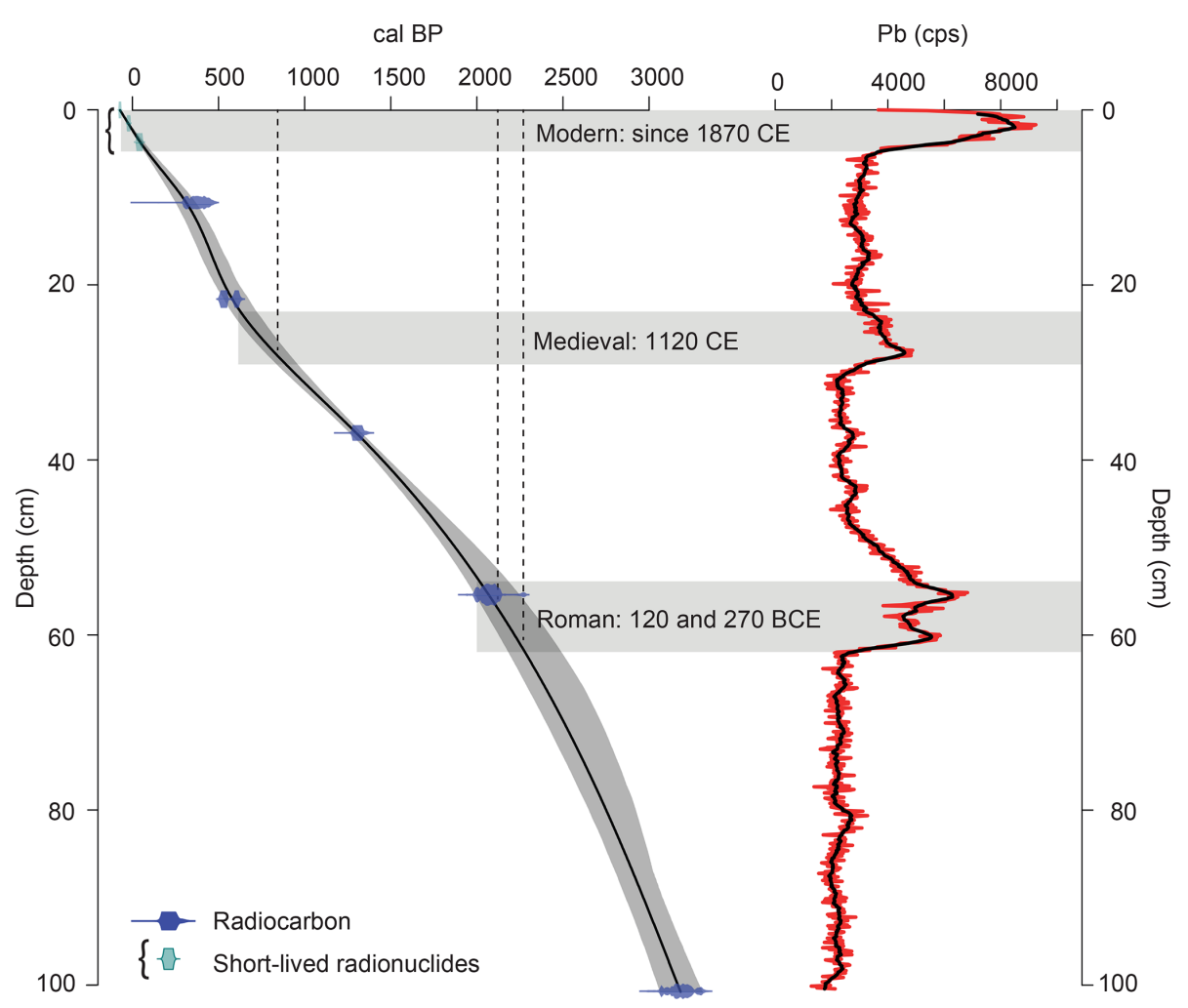

Figure 3. Age-depth model of the $102 \mathrm{~cm}$ Lake Bastani sedimentary sequence (BAS13P4), including ${ }^{210} \mathrm{~Pb} /{ }^{137} \mathrm{Cs}$ chronology (Fig. S4) and ${ }^{14} \mathrm{C}$ ages (Table 1). Lead measurement in the lake sediments with the identification of three pollution peaks and associated ages.

correlated with the BAS13P4 core (Fig. S2). Age modeling provided a precise age model over the last $3150 \mathrm{cal} \mathrm{BP}$, with an average sedimentation rate of $0.34 \mathrm{~mm} \mathrm{yr}^{-1}$ (Fig. 3), using clam software (Blaauw, 2010). This age model is confirmed by three $\mathrm{Pb}$ peaks: in the Roman period (with a double peak centered at 270 and $120 \mathrm{BCE}$ ), the medieval period $(1120 \mathrm{CE})$, and the modern industrial period starting at $1870 \mathrm{CE}$, with a maximum between 1970 and $1980 \mathrm{CE}$ (Fig. 3) related to $\mathrm{Pb}$ additives in gasoline. The two older $\mathrm{Pb}$ peaks correspond to well-known past metallurgic activities in the Mediterranean area (Elbaz-Poulichet et al., 2011) and demonstrate that the age model is well-defined and that this lake system is ideal for recording atmospheric inputs.

\section{Discussion}

\subsection{Sediment sources}

In northern Africa, the ratios of clay minerals, such as illite to kaolinite (I/K ratio) and chlorite to kaolinite $(\mathrm{C} / \mathrm{K}$ ratio), can serve as "fingerprints" of specific source areas (Bout-Roumazeilles et al., 2007; Caquineau, 2002; Guieu et al., 2002) (Fig. 1). The fibrous clay mineral (palygorskite), typical of arid to semiarid areas, appears to be a suitable source marker for the northern and western Sahara (PSA1 and PSA2) with high content, while the Sahel (PSA3) presents less palygorskite (Bout-Roumazeilles et al., 2013). The 3150 cal BP Lake Bastani sediment record reveals a relatively high percent of palygorskite in the clay mineral fraction; therefore, African dust deposits constitute a major part of the fine terrigenous flux in this lake (Fig. 4a). Palygorskite is also highly variable inside each source, and even if its content could reach $75 \%$ and $45 \%$ in some areas of PSA2 and PSA1, respectively (Grousset et al., 1992), the mean value of $11.6 \pm 3.6 \%$ in the Bastani record could indicate a degradation of this fibrous mineral during long wind transport as previously observed for river transport (Bout-Roumazeilles et al., 2007). The $\mathrm{I} / \mathrm{K}$ ratio (around $1.21 \pm 0.22$ ) is typical of the northern Saharan source (PSA1: $1<\mathrm{I} / \mathrm{K}<2$ ) but if we consider multiple sources contributions this ratio could result from a mix between the western Sahara (PSA2: I/K $>1.6$ ) and Sahel (PSA3: $0.3<\mathrm{I} / \mathrm{K}<0.7$ ) (Fig. 4b). The low value of the $\mathrm{C} / \mathrm{K}$ ratio (mean: $0.51 \pm 0.15$ ) is typical of the western Saharan source (PSA2: $0<\mathrm{C} / \mathrm{K}<0.8$ ) or the Sahel (PSA3: $0.2<\mathrm{C} / \mathrm{K}<0.9)$ but far from PSA1 $(\mathrm{C} / \mathrm{K}=1.5)$, except for the upper part of the record (Fig. 4c). Thus, if we consider these two ratios together the main dust sources are a mix between western Saharan and Sahelian except for the recent part, with an increasing influence of the northern Sahara (PSA1). Even if palygorskite is relatively low in regards to source contents from PSA1 and PSA2, the decreasing trend in palygorskite content probably reflects a progressive trend 


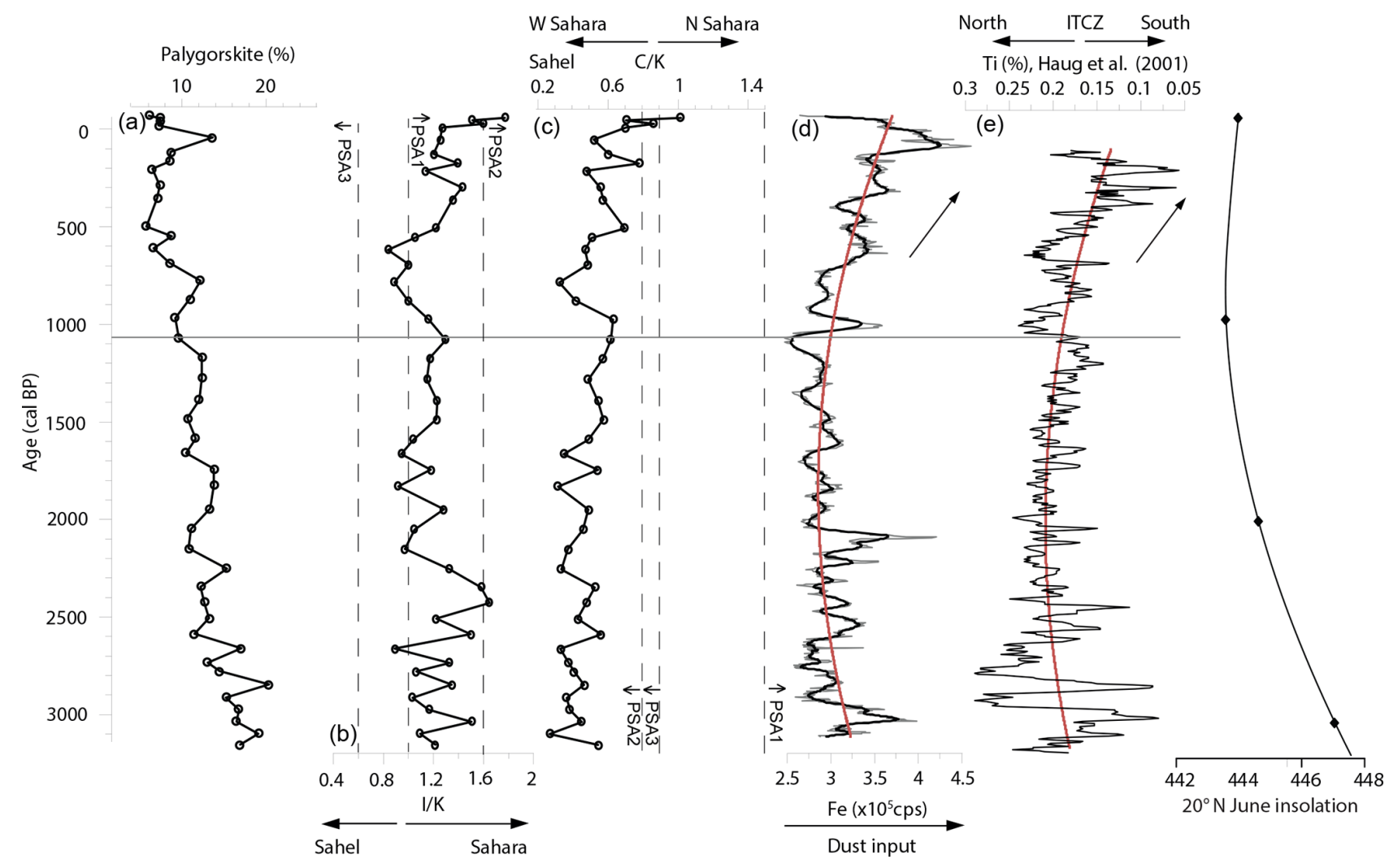

Figure 4. (a) Palygorskite content (\%). (b) I/K (illite to kaolinite) ratio to discriminate the source area of the Sahel (PSA3) from the Sahara (PSA1 and PSA2). (c) C/K (chlorite to kaolinite) ratio to discriminate source areas in the northern Sahara (PSA1) from the western Sahara (PSA2). Vertical dashed lines represent the upper and lower boundary of African sources. (d) Fe content interpreted as total dust input. (e) Variation of the ITCZ position (Haug et al., 2001) with reverse scale. (f) $20^{\circ} \mathrm{N}$ June insolation from Berger and Loutre (1991). Red curves present the long-term trend, and black arrows indicate a common variation. The horizontal gray line at 1071 cal BP represents this break-point analysis on the linear regression model between Fe content (dust input) and the ITCZ.

with more influence from PSA1 (Bout-Roumazeilles et al., 2013; Grousset et al., 1992) through time, also supported by the increasing trend of the $\mathrm{C} / \mathrm{K}$ ratio and higher value for the upper part of the record (Fig. 4). Modern dust provenance areas identified for Corsica through air mass trajectories over 1.5 years identify a dominant dust flux originating from the western $(>30 \%)$ and northern $(25 \%-30 \%)$ Sahara and a low contribution from the Sahel $(<5 \%)$ (Vincent et al., 2016), in agreement with recent source reconstitutions in the Bastani record. Longer instrumental records also identify African dust input to Corsica from northern Sahel sources (Fig. 1; Bergametti et al., 1989; Guieu et al., 2002).

The NCIR (eolian, watershed, biogenic silica) flux for the last century in Lake Bastani is $4.5 \mathrm{~g} \mathrm{~m}^{2} \mathrm{yr}^{-1}$. In comparison, the longest deposition dust fluxes measured in Corsica (10 years) vary between 4 and $26 \mathrm{~g} \mathrm{~m}^{2} \mathrm{yr}^{-1}$ (LoÿePilot, M.D. and Martin, 1996), with the lower value of this range corresponding to the NCIR flux calculated from the Lake Bastani sediment core. Even a low dust deposition year (2013: $2.1 \mathrm{~g} \mathrm{~m}^{2} \mathrm{yr}^{-1}$ ) (Vincent et al., 2016) corresponds to half of the NCIR flux. Thus, even though eolian input may vary from one year to another, dust fluxes measured in Corsica may represent almost all of the silicate source to this system, and siliceous input from the watershed can be neglected in the variability of our reconstructed signal.

Geochemical data allow for the identification of two mains terrigenous end-members: lake sediment characterized by $\mathrm{Fe}_{2} \mathrm{O}_{3}, \mathrm{TiO}_{2}, \mathrm{MgO}$, and $\mathrm{Fe}_{2} \mathrm{O}_{3}$ and watershed samples mainly composed of $\mathrm{CaO}, \mathrm{K}_{2} \mathrm{O}, \mathrm{Na}_{2} \mathrm{O}$, and $\mathrm{MnO}$. According to a PCA of the geochemical dataset, the ratios $\mathrm{Fe} / \mathrm{Ca}$ vs. $\mathrm{Ti} / \mathrm{Ca}$ and $\mathrm{Fe} / \mathrm{K}$ vs. $\mathrm{Ti} / \mathrm{K}$ were used in order to compare the compositions of lake sediments and the associated watershed with dust deposits in NW Mediterranean (Spain; Avila et al., 1997, 2007) and central Mediterranean areas (Adriatic Sea, Italy, Sicily; Tomadin et al., 1984) (Fig. 2b). These data allow us to determine that the geochemical composition of lake sediment is similar to non-carbonated dust samples, with no evident contribution of the watershed end-member to the lake sediment, as all lake sediment samples fall in the African dust signature (light orange area in Fig. 2b), in agreement with previous finding on fluxes. From XRF measurements on lake sediment, the terrigenous elements 
present in the African dust, such as $\mathrm{Ti}$ and $\mathrm{Fe}$, are correlated $\left(r=0.72, p<10^{-16}\right)$, but the Fe signal is less noisy. Moreover, $\mathrm{Fe}, \mathrm{Ca}$, and $\mathrm{K}$ contents present the same variations with good correlation (Fe vs. Ca $r=0.63, p<10^{-16}$; Fe vs. $\mathrm{K} r=0.63, p<10^{-16}$ ) in lake sediment, indicating that even for the terrigenous elements typical of the watershed $(\mathrm{Ca}, \mathrm{K}$; Fig. 2b), most of the variation is influenced by African dust, in good agreement with the NCIR flux estimation. This very low contribution of terrigenous elements from the watershed precluded the $\mathrm{Fe} / \mathrm{Ca}$ or $\mathrm{Fe} / \mathrm{K}$ ratio as a proxy for dust input. In African dust, iron is present in $\mathrm{Fe}$ containing silicate, iron oxide, and hydroxide coating and cement on grains, as well as in the lattice of clay minerals (Formenti et al., 2011; Scheuvens et al., 2013). Considering (1) the high Fe content in African dust, (2) the negligible input from the watershed, (3) no grain size variations in the Lake Bastani sediment (SI1), (4) low sedimentation rate changes (Fig. 2), and (5) good correlation between the XRF core scanner and $\mathrm{Fe}_{2} \mathrm{O}_{3}$ concentrations, the $\mathrm{Fe}$ content measured by XRF has been used to reconstruct African dust input variations through time (Fig. 4d). Ca is classically used as a tracer for carbonate minerals (calcite and dolomite) and is present in African dust; however, carbonate was not identified in the Lake Bastani sediment using infrared spectrometry (data not shown) and LOI. The absence of carbonate in the sediment could be linked to calcite dissolution during both atmospheric transport (Avila et al., 2007) and deposition in the lake water.

\subsection{African dust input and climate forcing}

\subsubsection{Millennial variation}

High-resolution (3-year) Fe content over the last 3150 years shows a long-term variation with a significant increase from approximately $1000 \mathrm{cal} \mathrm{BP}$ and centennial-scale variations, as well as an increase during the Little Ice Age (650$50 \mathrm{cal} \mathrm{BP}$ ) (Fig. 4d). This increase in dust input is earlier than previously published by Mulitza et al. (2010) in the Atlantic area, which the authors attributed to human contributions through changes in agriculture in the Sahel region (beginning of the 19th century).

We calculate the long-term trend (centennial to millennial) using the cubic model, which allows for the reconstruction of the long-term dust signal in Lake Bastani. This millennialscale variation shows an increasing trend, similar to the longterm southward migration of the ITCZ (Haug et al., 2001) (Fig. 4d, e) in response to a gradual orbitally induced decrease in Northern Hemisphere insolation. These two longterm reconstructed trends present a good correlation $\left(R^{2}=\right.$ $0.90, p$ value $<2.2 \times 10^{-16}, F$ statistic $\left.=4857\right)$. A breakpoint analysis on the linear regression model between the two initial signal shows a change at 1070 cal BP (Fig. 4), with a positive trend since that time. Modern increases in boreal winter and summer dust emissions are correlated with a southerly position of the ITCZ over North Africa, associated with increased surface winds over central and western North Africa (Doherty et al., 2012, 2014). The annual dust cycle may be partly explained by seasonal changes in the positions of the Intertropical Convergence Zone (ITCZ) and associated rainfall distributions. The most northern position of the ITCZ is responsible for the rainy (monsoon) season; rainfall reduces the atmospheric dust content through increases in soil moisture and vegetation cover, reducing dust emissions from the ground and cleaning the atmosphere by removing dust particles (wet deposition) (Engelstaedter et al., 2006). This correlation could reflect the availability of dust sources for mobilization, suggesting a long-term forcing of the southward ITCZ migration on the increased dust export to the Mediterranean area since $1070 \mathrm{cal} \mathrm{BP}$. Over a longer period, such a link is also observed, with a drastic decline in dust flux occurring during the AHP (11 to 7-5 ka) related to a combination of decreased wind and increased precipitation, which is associated with a northward shift of the ITCZ (Bout-Roumazeilles et al., 2007; McGee et al., 2013; Rodrigo-Gámiz et al., 2011; Zielhofer et al., 2017) in relation to the increase in summer orbital insolation (deMenocal et al., 2000).

\subsubsection{Centennial variation}

Reconstructed African dust input also presents high shortterm variation at a centennial to decadal timescale. Over the last century, we observed from $\mathrm{Fe}$ data an African dust increase that reached a maximum between 1945 and 1975 and then a decrease until today, like the decreasing trend observed by Evan and Mukhopadhyay (2010). African dust input variations on Corsica are potentially linked to the availability of dust sources that could be mobilized and to the transport pathway that allows dust to reach this island.

A recent study, based on a comparison between dust time series and projections of the wind pattern onto climate models, shows that wind intensity is an important factor controlling African dust variability over the last several decades, and this explains why time series of dust are correlated with diverse climate phenomena such as the NAO, ITCZ, and Sahelian drought (Evan et al., 2016). To test such relationships over the last millennia wavelet analyses have been performed on the Bastani dust inputs, total solar irradiance (TSI) (Steinhilber et al., 2012), the ITCZ (Haug et al., 2001), ENSO (Moy et al., 2002), and the North Atlantic Oscillation (NAO) (Franke et al., 2017) reconstructions. They highlight significant cyclicities (up to more than the $95 \%$ level of confidence; Fig. 5). The scalogram of dust inputs (Fe) presents three different cycles of approximately 200,300, and 450 years (Fig. 5a). The power spectra of the ITCZ and ENSO reconstructions do not show significant cycles in this period, except between 2500 and 3100 cal BP for the ITCZ reconstruction with a period of approximately 200 years common with the dust signal (Fig. 5b) and a large oscillation in the ITCZ 

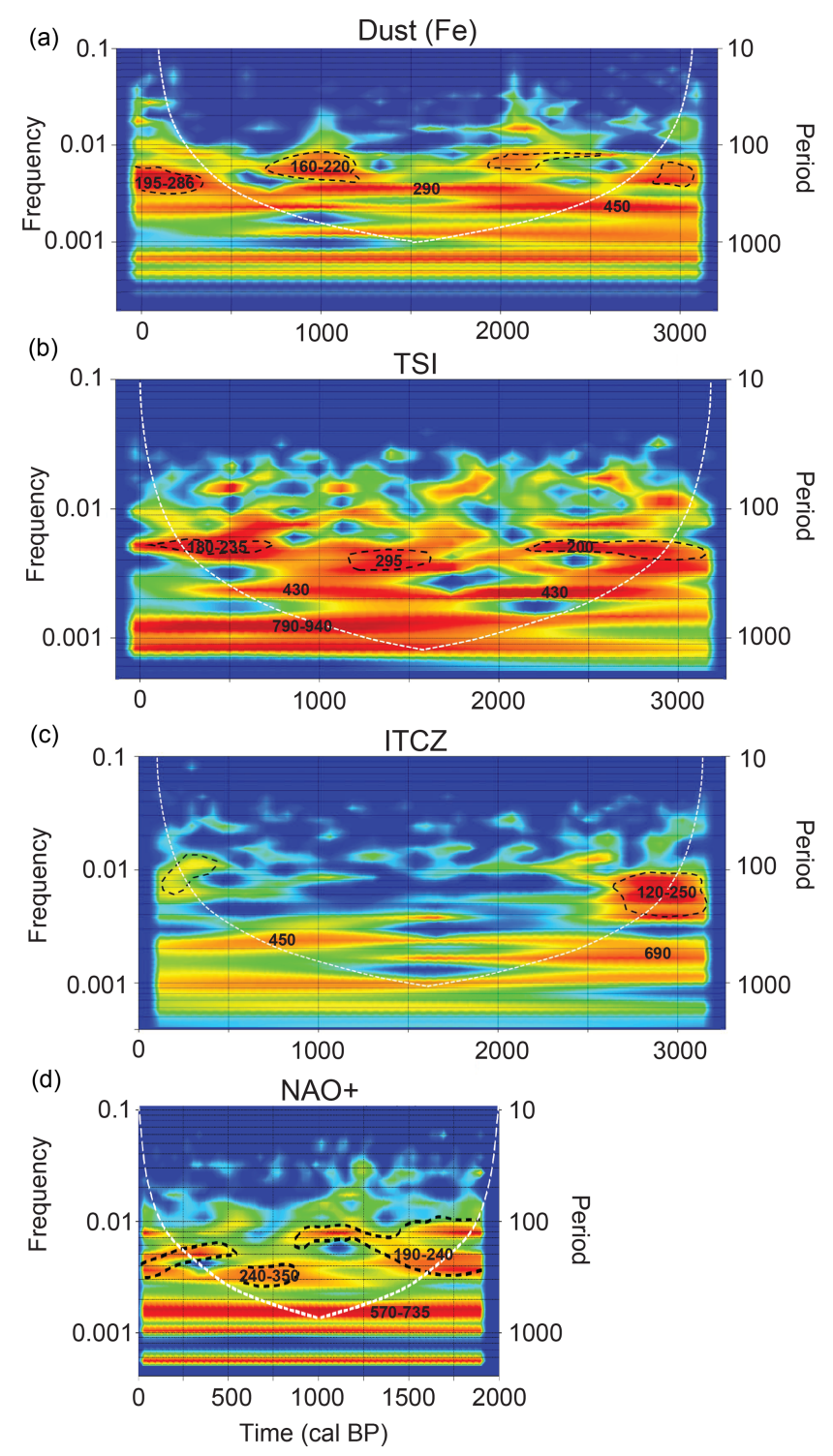

Figure 5. Individual wavelet analyses for (a) dust content (Fe, Lake Bastani), (b) TSI (Steinhilber et al., 2012), (c) ITCZ (Haug et al., 2001), and (d) NAO+ (Franke et al., 2017) signals. The NAO signal covers the last 2000 years. The occurrence of periods (labeled in black) with respect to time is given by the bright yellow-red colors. The $95 \%$ confidence levels are indicated with the dotted line.

position (wavelet analyses not shown for ENSO). We use a recent NAO reconstruction for the last 2000 years (Franke et al., 2017), based on 37 highly resolved proxy records following the recommendation of Ortega et al. (2015), which showed that an NAO index reconstruction based on two proxies is not sufficient to define long-term NAO variability. While this record only covers the last 2 millennia, wavelet analyses have been performed and display cycles of approximately 200 and 300 years (Fig. 5d). Cross-wavelet analysis between dust input and the NAO signal over the last 2000 years highlights a period of high (low) dust inputs in
Corsica corresponding to a positive (negative) NAO index over the last millennium (Fig. 6a). During the positive NAO phase, the pressure gradient between the Icelandic low and the subtropical high is more intense than normal and westerly winds are stronger across northern Europe, which is associated with mild temperatures and higher precipitation, while drier conditions than usual are produced at lower latitudes across southern Europe. Moulin et al. (1997) showed that, over the modern period, the positive NAO phase, with drier conditions over southern Europe, the Mediterranean Sea, and northern Africa, induced higher dust transport and affected both the pattern and intensity of the transport of African dust. When the NAO is negative, the pressure gradient decreases and the westerlies are shifted to the south, providing precipitation over the Mediterranean and the North African continent and restricting dust uptake and transport (Moulin et al., 1997). The correlation between the positive summer $\mathrm{NAO}$ and a high dust contribution has been identified more recently in an 11-year (2001-2011) record (Pey et al., 2013). But, even if in our record we compare the dust signal (mainly spring and summer) with the yearly index of the NAO, this strong relation appeared since $\sim 1000 \mathrm{cal} \mathrm{BP}$ (Fig. 6a), which corresponds to the period of a long-term increase in African dust correlated with the southward ITCZ migration (Fig. 4), suggesting that long-term forcing through ITCZ migration has an impact on the NAO-African dust correlation. This influence can be explained by the fact that the ITCZ and westerlies are both linked to the Hadley cell through the North Atlantic subtropical high, and the position of the westerlies is influenced by the NAO (Souza and Cavalcanti, 2009). During the positive phase of the NAO with a strong North Atlantic subtropical high, the ITCZ is displaced southward in April (Souza and Cavalcanti, 2009). Here we suggest that a longterm southward position of the ITCZ over the last millennium may have enhanced NAO forcing on African dust inputs to the western Mediterranean area in spring and summer.

The scalogram of TSI reconstructions shows significant periodicities already known from cosmic-ray-produced radionuclide records (Steinhilber et al., 2012), such as the period of $\sim 200$ years corresponding to the de Vries cycle and the period of $\sim 300$ years to a lesser extent, with a less significant one of around 430 years. These two significant cycles are the same as the two shorter cycles observed in the dust inputs (Fig. 5a, b). Cross-wavelet analysis between dust input and the TSI signal over the last 3000 years highlights a period of high (low) dust inputs in Corsica corresponding to a low (high) TSI between 3000 and $1000 \mathrm{cal} \mathrm{BP}$ with a shift from the 200- to the 300-year cycles around 2000 cal BP (Fig. 6b). Variation in solar ultraviolet (UV) radiation affects the stratospheric ozone, leading to temperature variations in the top stratosphere. The resulting temperature gradients lead to changes in the zonal wind, which change the planetary wave-mean flow interactions and appear to be an indirect effect of the changes in the global atmospheric circulation through the "top-down" mechanism (Gray et al., 2010). 

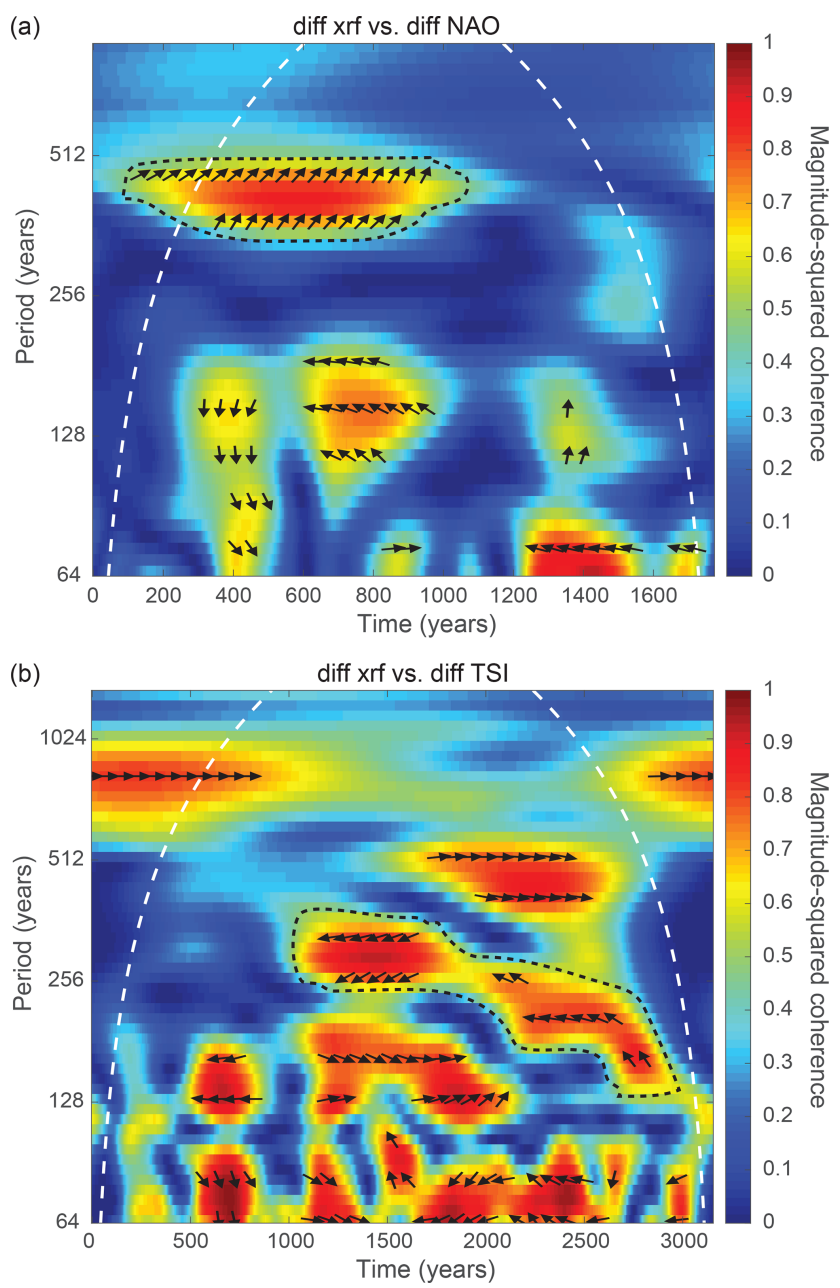

Figure 6. Cross-wavelet analyses for dust input versus NAO (a) and TSI (b). The dotted line represents an identified significant cycle for each signal in single wavelet analyses (Fig. 5). Right and left arrows are respectively in phase or in phase opposition, and up and down arrows respectively show the first or second signal that predates the other one.

Thus, small changes in solar radiation might indirectly affect the climate by inducing atmospheric changes, such as in the large European Atlantic sector with wind and precipitation changes (Martin-Puertas et al., 2012) or in the Mediterranean area, which results in both increased storminess (Sabatier et al., 2012) and a higher flood frequency (Sabatier et al., 2017; Vannière et al., 2013).

To explain the link we found between TSI and dust records, we argue that changes in the TSI can (slightly) modify the main wind patterns. Indeed, a decrease in TSI diminishes the surface solar insolation in tropical area, especially in cloud-free areas, which can decrease evaporation there and then the moisture transport into the precipitation convergence zone, leading to a weakening of the Hadley cell, as illustrated in some model simulations (Meehl et al., 2004). Such a weakening can then induce in the subsidence zone a decrease (a) Solar variations

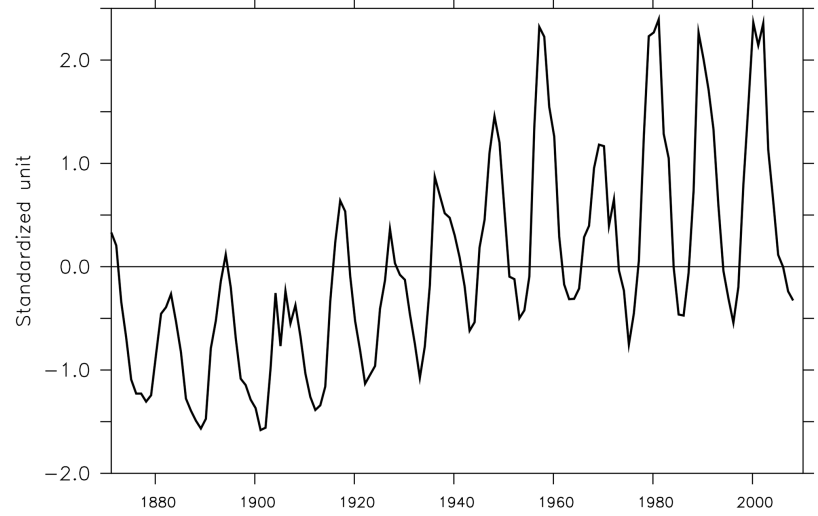

(b) Inverse regression SLP (MAM) over solar variations

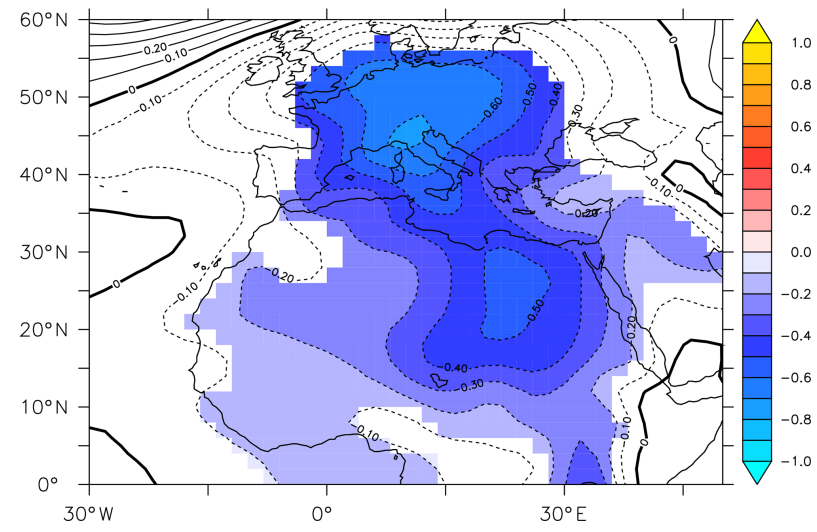

Figure 7. (a) Total solar irradiance variations (standardized over the whole period) from Lean (2009). (b) Regression (hPa / TSI SD) of the sea level pressure data from the 20CR reanalysis over the TSI variations for the period 1870-2009 in spring (March, April, May: MAM). Only the values significant at the $95 \%$ level appear in color, while the contours show all the computed values.

in the magnitude of anticyclones over North Africa, i.e., a negative sea level pressure or low-pressure anomaly. Such a low-pressure anomaly is known to increase the dust transport over the recent period (Moulin et al., 1998). To support this link between the TSI and changes in the pressure pattern over North Africa, as the amplitude of centennial variability may be of the same order of magnitude as the wellobserved 11-year cycle, we performed a regression analysis over the instrumental period using the TSI reconstruction (Lean, 2009) and the NOAA 20CR reanalysis (Compo et al., 2011). We find in spring a significant negative anomaly in pressure when TSI is decreasing (Fig. 7), which is in line with the mechanism depicted before. Even if TSI variations are weak, this regression analysis show that such an amplitude is likely sufficient to have a significant impact on the climatic system. Moreover, this mechanism could be also associated with the Saharan Heat Low (SHL), an area of high surface temperature and low surface pressure within the summertime Sahara, when SHL cools, wind speed increases over 
the Sahara, and increasing dust emission from the major dust sources in the Sahara is observed (Wang et al., 2015, 2017). Therefore, we argue that such a relatively simple process, observed over the last century and already found in model simulations concerning the weakening of the Hadley cell (Meehl et al., 2004), can explain the link we found between a low TSI and higher dust input records in Corsica for the period between 3000 and $1000 \mathrm{cal}$ BP. Thus, we hypothesize here that when the ITCZ is in a more northern position (before 1070 cal BP) such a mechanism is enhanced through changes in wind intensity and the transport pathways of dust into the western Mediterranean area. The mechanism proposed does not account for the potential impact feedback of atmospheric circulation on dust emissions or the impact on solar irradiance reaching the surface (Alonso-Montesinos et al., 2017; Granados-Muñoz et al., 2019; Kosmopoulos et al., 2017).

\section{Conclusions}

A high-elevation sediment record from Lake Bastani on Corsica in the northwestern Mediterranean Sea allows for a reconstruction of high-resolution African dust variability over the last 3150 years. Thanks to mineralogical and geochemical analyses we can unambiguously determine that African dust is the main terrigenous sediment component. This multiproxy approach reveals that both the western Sahara and Sahel are the main African dust sources to the western Mediterranean area, with a more important influence of the northern Sahara over the last centuries, in agreement with the modern dust provenance areas identified for Corsica through air mass trajectories. We suggest that the millennial-scale variations of Saharan dust inputs could be forced by the southward migration of the ITCZ, with an increase since $1070 \mathrm{cal}$ BP in response to a gradual orbitally induced decrease in Northern Hemisphere insolation. This correlation could reflect the increased availability of dust sources to be mobilized by an increase in wind and a decrease in precipitation, soil moisture, and vegetation cover over North Africa. At the centennial timescale, the NAO and TSI are the two main climate forcings identified, but their respective influences seem to be related to the ITCZ migration. Since $1070 \mathrm{cal}$ BP (ITCZ southern position) the NAO has been the dominant climate forcing, with an increase in Saharan dust input during the NAO positive phase and drier conditions over southern Europe, the Mediterranean Sea, and northern Africa affecting both the pattern and intensity of the transport of African dust, as observed from the instrumental period. Even if a precise NAO reconstitution is not available before 2000, wavelet analysis shows that between 3150 and 1070 cal BP (ITCZ in a more northern position) the centennial increases in Saharan dust inputs are correlated with a low TSI. During the instrumental era, we observe during low TSI a significant negative anomaly in pressure over Africa, which is known to increase the dust transport over the recent period. We suggest that when the ITCZ is in a more northern position such an atmospheric mechanism is enhanced and induces changes in wind intensity and the transport pathways of dust into the western Mediterranean area. As long-term ITCZ migration reflects the availability of dust sources to be mobilized, the NAO and TSI modulate short-term Saharan dust inputs to the western Mediterranean area through changes in wind and transport pathways. The highlighting of these three climatic controls on dust inputs at different timescales allows for a better definition of dust-climate interactions from a long-term perspective.

Data availability. Core data are all stored in PANGEA (https: //doi.pangaea.de/10.1594/PANGAEA.910655, last access: 14 January 2020).

Supplement. The supplement related to this article is available online at: https://doi.org/10.5194/cp-16-283-2020-supplement.

Author contributions. $\mathrm{PS}, \mathrm{BV}, \mathrm{MD}$, and $\mathrm{CP}$ designed the research; PS, CC, EM, MCB, BC, JLR, ALD, YC, JD, IJB, CP, DS, $\mathrm{MK}$, and JP performed the research; PS, MN, YP, CC, BV, DS, CS, ML, and MD contributed new reagents and analytic tools; PS, YP, MN, BV, DS, CS, ML, and MD analyzed data; and PS, MN, CC, $\mathrm{MD}, \mathrm{BV}, \mathrm{DS}$, and FA wrote the paper.

Competing interests. The authors declare that they have no conflict of interest.

Acknowledgements. We thank the Office Environemental Corse (OEC; Gwenaëlle Baldovini and Pierre-Jean Albertini), the Parc Naturel Regional de Corse, and the Direction regionale de l'Environnement, de l'Aménagement et du Logement de Corse (DREAL) for the coring authorization and support during fieldwork. The authors would like to thank Marie-Dominique Loÿe-Pilot for paper reading, Victor Froissard for help with R Code, Jérôme Debret for his help during the field trip, and Cécile Pignol for data and metadata good practices. Some of the ${ }^{14} \mathrm{C}$ analyses were acquired thanks to the CNRS-INSU ARTEMIS national radiocarbon AMS measurement program at Laboratoire de Mesure ${ }^{14} \mathrm{C}$ (LMC14) in the CEA Institute at Saclay (French Atomic Energy Commission). The figure about short-lived radionuclides was computed thanks to a code developed by Rosalie Bruel (manuscript in preparation). The authors would also like to thank the Laboratoire Souterrain de Modane facilities for the gamma spectrometry measurements and Environnement, Dynamique et Territoires de Montagne for the Xray fluorescence analyses. We thank Nathalie Combourieu-Nebout and two anonymous reviewers for their comments and suggestions that improved the paper. 
Financial support. This research is part of the HoTMED project (led by Boris Vannière) and is funded by the Région Franche-Comté through the University of Franche-Comté as well as by the CNRS through the PaleoMEx-INEE program.

Review statement. This paper was edited by Nathalie Combourieu Nebout and reviewed by two anonymous referees.

\section{References}

Aitchison, J., Barcelo-Vidal, C., Egozcue, J. J., and PawlowskyGlahn, V.: A concise guide for the algebraic - geometric structure of the simplex, the sample space for compositional data analysis, in: Proceedings of IAMG'02 - The Eighth Annual Conference of the International Association for Mathematical Geology, edited by: Bayer, U., Burger, H., and Skala, W., Berlin, Germany, 387392, 2002.

Albani, S., Mahowald, N. M., Winckler, G., Anderson, R. F., Bradtmiller, L. I., Delmonte, B., François, R., Goman, M., Heavens, N. G., Hesse, P. P., Hovan, S. A., Kang, S. G., Kohfeld, K. E., Lu, H., Maggi, V., Mason, J. A., Mayewski, P. A., McGee, D., Miao, X., Otto-Bliesner, B. L., Perry, A. T., Pourmand, A., Roberts, H. M., Rosenbloom, N., Stevens, T., and Sun, J.: Twelve thousand years of dust: the Holocene global dust cycle constrained by natural archives, Clim. Past, 11, 869-903, https://doi.org/10.5194/cp-11869-2015, 2015.

Alonso-Montesinos, J., Barbero, J., Polo, J., López, G., Ballestrín, J., and Batlles, F. J.: Impact of a Saharan dust intrusion over southern Spain on DNI estimation with sky cameras, Atmos. Environ., 170, 279-289, https://doi.org/10.1016/j.atmosenv.2017.09.040, 2017.

Arnaud, F., Lignier, V., Revel, M., Desmet, M., Beck, C., Pourchet, M., Charlet, F., Trentesaux, A., and Tribovillard, N.: Flood and earthquake disturbance of ${ }^{210} \mathrm{~Pb}$ geochronology (Lake Anterne, NW Alps), Terra Nova, 14, 225-232, https://doi.org/10.1046/j.1365-3121.2002.00413.x, 2002.

Avila, A., Queralt-Mitjans, I., and Alarcón, M.: Mineralogical composition of African dust delivered by red rains over northeastern Spain, J. Geophys. Res.-Atmos., 102, 21977-21996, https://doi.org/10.1029/97JD00485, 1997.

Avila, A., Alarcón, M., Castillo, S., Escudero, M., García Orellana, J., Masqué, P. and Querol, X.: Variation of soluble and insoluble calcium in red rains related to dust sources and transport patterns from North Africa to northeastern Spain, J. Geophys. Res., 112, 1-14, https://doi.org/10.1029/2006JD007153, 2007.

Bajard, M., Sabatier, P., David, F., Develle, A.-L., Reyss, J.-L., Fanget, B., Malet, E., Arnaud, D., Augustin, L., Crouzet, C., Poulenard, J., and Arnaud, F.: Erosion record in Lake La Thuile sediments (Prealps, France): Evidence of montane landscape dynamics throughout the Holocene, The Holocene, 26, 350-364, https://doi.org/10.1177/0959683615609750, 2016.

Bergametti, G., Gomes, L., Remoudaki, E., Desbois, M., Martin, D., and Buat-Ménard, P.: Present Transport and Deposition Patterns of African Dusts to the North-Western Mediterranean, in Paleoclimatology and Paleometeorology: Modern and Past Patterns of Global Atmospheric Transport, edited by: Leinen, M. and Sarnthein, M., Springer Netherlands, Dordrecht, 227-252, 1989.
Berger, A. and Loutre, M. F.: Insolation values for the climate of the last 10 million years, Quat. Sci. Rev., 10, 297-317, https://doi.org/10.1016/0277-3791(91)90033-Q, 1991.

Blaauw, M.: Methods and code for "classical" age-modelling of radiocarbon sequences, Quat. Geochronol., 5, 512-518, https://doi.org/10.1016/j.quageo.2010.01.002, 2010.

Bout-Roumazeilles, V., Combourieu Nebout, N., Peyron, O., Cortijo, E., Landais, A., and Masson-Delmotte, V.: Connection between South Mediterranean climate and North African atmospheric circulation during the last $50000 \mathrm{yr} \mathrm{BP}$ North Atlantic cold events, Quat. Sci. Rev., 26, 3197-3215, https://doi.org/10.1016/j.quascirev.2007.07.015, 2007.

Bout-Roumazeilles, V., Combourieu-Nebout, N., Desprat, S., Siani, G., Turon, J.-L., and Essallami, L.: Tracking atmospheric and riverine terrigenous supplies variability during the last glacial and the Holocene in central Mediterranean, Clim. Past, 9, 10651087, https://doi.org/10.5194/cp-9-1065-2013, 2013.

Bruel, R. and Sabatier, P.: serac: a R package for ShortlivEd RAdionuclide Chronology of recent sediment cores, https://doi.org/10.31223/osf.io/f4yma, 1-38, 2020.

Caquineau, S.: Mineralogy of Saharan dust transported over northwestern tropical Atlantic Ocean in relation to source regions, J. Geophys. Res., 107, 1-14, https://doi.org/10.1029/2000JD000247, 2002.

Carignan, J., Hild, P., Mevelle, G., Morel, J., and Yeghicheyan, D.: Routine Analyses of Trace Elements in Geological Samples using Flow Injection and Low Pressure On-Line Liquid Chromatography Coupled to ICP-MS: A Study of Geochemical Reference Materials BR, DR-N, UB-N, AN-G and GH, Geostand. Geoanal. Res., 25, 187-198, https://doi.org/10.1111/j.1751908X.2001.tb00595.x, 2001.

Cockerton, H. E., Holmes, J. A., Street-Perrott, F. A., and Ficken, K. J.: Holocene dust records from the West African Sahel and their implications for changes in climate and land surface conditions, J. Geophys. Res.-Atmos., 119, 8684-8694, https://doi.org/10.1002/2013JD021283, 2014.

Colin, C., Turpin, L., Bertaux, J., Desprairies, A., and Kissel, C.: Erosional history of the Himalayan and Burman ranges during the last two glacial-interglacial cycles, Earth Planet. Sc. Lett., 171, 647-660, https://doi.org/10.1016/S0012-821X(99)00184-3, 1999.

Compo, G. P., Whitaker, J. S., Sardeshmukh, P. D., Matsui, N., Allan, R. J., Yin, X., Gleason, B. E., Vose, R. S., Rutledge, G., Bessemoulin, P., Brönnimann, S., Brunet, M., Crouthamel, R. I., Grant, A. N., Groisman, P. Y., Jones, P. D., Kruk, M. C., Kruger, A. C., Marshall, G. J., Maugeri, M., Mok, H. Y., Nordli, Ø., Ross, T. F., Trigo, R. M., Wang, X. L., Woodruff, S. D., and Worley, S. J.: The Twentieth Century Reanalysis Project, Q. J. Roy. Meteor. Soc., 137, 1-28, https://doi.org/10.1002/qj.776, 2011.

deMenocal, P., Ortiz, J., Guilderson, T., Adkins, J., Sarnthein, M., Baker, L., and Yarusinsky, M.: Abrupt onset and termination of the African Humid Period, Quat. Sci. Rev., 19, 347-361, https://doi.org/10.1016/S0277-3791(99)00081-5, 2000.

Doherty, O. M., Riemer, N. and Hameed, S.: Control of Saharan mineral dust transport to Barbados in winter by the Intertropical Convergence Zone over West Africa: winter dust in Barbados and the ITCZ, J. Geophys. Res.-Atmos., 117, D19117, https://doi.org/10.1029/2012JD017767, 2012. 
Doherty, O. M., Riemer, N., and Hameed, S.: Role of the convergence zone over West Africa in controlling Saharan mineral dust load and transport in the boreal summer, Tellus B, 66, 23191, https://doi.org/10.3402/tellusb.v66.23191, 2014.

Ehrmann, W., Schmiedl, G., Beuscher, S., and Krüger, S.: Intensity of African Humid Periods Estimated from Saharan Dust Fluxes, edited by: Xie, S.-P., PLOS ONE, 12, e0170989, https://doi.org/10.1371/journal.pone.0170989, 2017.

Elbaz-Poulichet, F., Dezileau, L., Freydier, R., Cossa, D., and Sabatier, P.: A 3500-Year Record of $\mathrm{Hg}$ and $\mathrm{Pb}$ Contamination in a Mediterranean Sedimentary Archive (The Pierre Blanche Lagoon, France), Environ. Sci. Technol., 45, 86428647, https://doi.org/10.1021/es2004599, 2011.

Engelstaedter, S., Tegen, I., and Washington, R.: North African dust emissions and transport, Earth Sci. Rev., 79, 73-100, https://doi.org/10.1016/j.earscirev.2006.06.004, 2006.

Evan, A. T. and Mukhopadhyay, S.: African Dust over the Northern Tropical Atlantic: 1955-2008, J. Appl. Meteorol. Clim., 49, 2213-2229, https://doi.org/10.1175/2010JAMC2485.1, 2010.

Evan, A. T., Flamant, C., Gaetani, M., and Guichard, F.: The past, present and future of African dust, Nature, 531, 493-495, https://doi.org/10.1038/nature17149, 2016.

Formenti, P., Schütz, L., Balkanski, Y., Desboeufs, K., Ebert, M., Kandler, K., Petzold, A., Scheuvens, D., Weinbruch, S., and Zhang, D.: Recent progress in understanding physical and chemical properties of African and Asian mineral dust, Atmos. Chem. Phys., 11, 8231-8256, https://doi.org/10.5194/acp11-8231-2011, 2011.

Franke, J. G., Werner, J. P., and Donner, R. V.: Reconstructing Late Holocene North Atlantic atmospheric circulation changes using functional paleoclimate networks, Clim. Past, 13, 1593-1608, https://doi.org/10.5194/cp-13-1593-2017, 2017.

Goudie, A. S. and Middleton, N. J.: Saharan dust storms: nature and consequences, Earth Sci. Rev., 56, 179-204, https://doi.org/10.1016/S0012-8252(01)00067-8, 2001.

Granados-Muñoz, M. J., Sicard, M., Román, R., Benavent-Oltra, J. A., Barragán, R., Brogniez, G., Denjean, C., Mallet, M., Formenti, P., Torres, B., and Alados-Arboledas, L.: Impact of mineral dust on shortwave and longwave radiation: evaluation of different vertically resolved parameterizations in 1-D radiative transfer computations , Atmos. Chem. Phys., 19, 523-542, https://doi.org/10.5194/acp-19-523-2019, 2019.

Gray, L. J., Beer, J., Geller, M., Haigh, J. D., Lockwood, M., Matthes, K., Cubasch, U., Fleitmann, D., Harrison, G., Hood, L., Luterbacher, J., Meehl, G. A., Shindell, D., van Geel, B., and White, W.: Solar influences on climate, Rev. Geophys., 48, 1-53, https://doi.org/10.1029/2009RG000282, 2010.

Grinsted, A., Moore, J. C., and Jevrejeva, S.: Application of the cross wavelet transform and wavelet coherence to geophysical time series, Nonlinear Proc. in Geoph., 11, 561-566, https://doi.org/10.5194/npg-11-561-2004, 2004.

Grousset, F. E., Rognon, P., Coudé-Gaussen, G., and Pédemay, P.: Origins of peri-Saharan dust deposits traced by their $\mathrm{Nd}$ and $\mathrm{Sr}$ isotopic composition, Palaeogeogr. Palaeocl., 93, 203-212, https://doi.org/10.1016/0031-0182(92)90097-O, 1992.

Guieu, C., Loÿe-Pilot, M.-D., Ridane, C., and Thomas, C.: Chemical characterization of the Saharan dust endmember: Some biogeochemical implications for the west- ern Mediterranean Sea, J. Geophys. Res., 107, 1-11, https://doi.org/10.1029/2001JD000582, 2002.

Haug, G. H., Hughen, K., Sigman, D. M., Peterson, L. C., and Röhl, U.: Southward Migration of the Intertropical Convergence Zone Through the Holocene, Science, 293, 1304-1308, https://doi.org/10.1126/science.1059725, 2001.

Heiri, O., Lotter, A. F., and Lemcke, G.: Loss on ignition as a method for estimating organic and carbonate content in sediments: reproducibility and comparability of results, J. Paleolimnol., 25, 101-110, https://doi.org/10.1023/A:1008119611481, 2001.

Jiménez-Espejo, F. J., García-Alix, A., Jiménez-Moreno, G., Rodrigo-Gámiz, M., Anderson, R. S., Rodríguez-Tovar, F. J., Martínez-Ruiz, F., Giralt, S., Delgado Huertas, A., and Pardo-Igúzquiza, E.: Saharan aeolian input and effective humidity variations over western Europe during the Holocene from a high altitude record, Chem. Geol., 374, 1-12, https://doi.org/10.1016/j.chemgeo.2014.03.001, 2014.

Kosmopoulos, P. G., Kazadzis, S., Taylor, M., Athanasopoulou, E., Speyer, O., Raptis, P. I., Marinou, E., Proestakis, E., Solomos, S., Gerasopoulos, E., Amiridis, V., Bais, A., and Kontoes, C.: Dust impact on surface solar irradiance assessed with model simulations, satellite observations and ground-based measurements, Atmos. Meas. Tech., 10, 2435-2453, https://doi.org/10.5194/amt10-2435-2017, 2017.

Le Roux, G., Fagel, N., De Vleeschouwer, F., Krachler, M., Debaille, V., Stille, P., Mattielli, N., van der Knaap, W. O., van Leeuwen, J. F. N., and Shotyk, W.: Volcano- and climatedriven changes in atmospheric dust sources and fluxes since the Late Glacial in Central Europe, Geology, 40, 335-338, https://doi.org/10.1130/G32586.1, 2012.

Lean, J.: Calculations of Solar Irradiance: monthly means from 1882 to 2008 , annual means from 1610 to 2008 , available at: http://www.geo.fu-berlin.de/en/met/ag/strat/forschung/ SOLARIS/Inputdata/ (last access: 5 April 2018), 2009.

Liu, Y., Zhang, M., Liu, Z., Xia, Y., Huang, Y., Peng, Y., and Zhu, J.: A Possible Role of Dust in Resolving the Holocene Temperature Conundrum, Sci. Rep., 8, 1-9, https://doi.org/10.1038/s41598018-22841-5, 2018.

Longman, J., Veres, D., Ersek, V., Salzmann, U., Hubay, K., Bormann, M., Wennrich, V., and Schäbitz, F.: Periodic input of dust over the Eastern Carpathians during the Holocene linked with Saharan desertification and human impact, Clim. Past, 13, 897917, https://doi.org/10.5194/cp-13-897-2017, 2017.

Loÿe-Pilot, M. D. and Martin, J. M.: Saharan dust input to the western Mediterranean: An eleven years records in Corsica, in: The Impact of Desert Dust across the Mediterranean, edited by: Guerzoni, S. and Chester, R., 191-199, 1996.

Maher, B. A., Prospero, J. M., Mackie, D., Gaiero, D., Hesse, P. P. and Balkanski, Y.: Global connections between aeolian dust, climate and ocean biogeochemistry at the present day and at the last glacial maximum, Earth Sci. Rev., 99, 61-97, https://doi.org/10.1016/j.earscirev.2009.12.001, 2010.

Martin-Puertas, C., Matthes, K., Brauer, A., Muscheler, R., Hansen, F., Petrick, C., Aldahan, A., Possnert, G., and van Geel, B.: Regional atmospheric circulation shifts induced by a grand solar minimum, Nat. Geosci., 5, 397-401, https://doi.org/10.1038/ngeo1460, 2012. 
Marx, S. K., Kamber, B. S., McGowan, H. A., Petherick, L. M., McTainsh, G. H., Stromsoe, N., Hooper, J. N., and May, J.-H.: Palaeo-dust records: A window to understanding past environments, Global Planet. Change, 165, 13-43, https://doi.org/10.1016/j.gloplacha.2018.03.001, 2018.

McGee, D., deMenocal, P. B., Winckler, G., Stuut, J. B. W., and Bradtmiller, L. I.: The magnitude, timing and abruptness of changes in North African dust deposition over the last $20000 \mathrm{yr}$, Earth Planet. Sc. Lett., 371, 163-176, https://doi.org/10.1016/j.epsl.2013.03.054, 2013.

Meehl, G. A., Washington, W. M., Wigley, T. M. L., Arblaster, J. M., and Dai, A.: Mechanisms of an Intensified Hadley Circulation in Response to Solar Forcing in the Twentieth Century, in: The Hadley Circulation: Present, Past and Future, Vol. 21, edited by: Diaz, H. F. and Bradley, R. S., Springer Netherlands, Dordrecht, 489-511, 2004.

Moulin, C., Lambert, C. E., Dulac, F., and Dayan, U.: Control of atmospheric export of dust from North Africa by the North Atlantic Oscillation, Nature, 387, 691-694, 1997.

Moulin, C., Lambert, C. E., Dayan, U., Masson, V., Ramonet, M., Bousquet, P., Legrand, M., Balkanski, Y. J., Guelle, W., Marticorena, B., Bergametti, G., and Dulac, F.: Satellite climatology of African dust transport in the Mediterranean atmosphere, J. Geophys. Res.-Atmos., 103, 1313713144, https://doi.org/10.1029/98JD00171, 1998.

Moy, C. M., Seltzer, G. O., Rodbell, D. T., and Anderson, D. M.: Variability of El Niño/Southern Oscillation activity at millennial timescales during the Holocene epoch, Nature, 420, 162-165, https://doi.org/10.1038/nature01194, 2002.

Muggeo, V.: Segmented: an R package to fit regression models with broken-line relationships, R News, 20-25, 2008.

Mulitza, S., Heslop, D., Pittauerova, D., Fischer, H. W., Meyer, I., Stuut, J.-B., Zabel, M., Mollenhauer, G., Collins, J. A., Kuhnert, H., and Schulz, M.: Increase in African dust flux at the onset of commercial agriculture in the Sahel region, Nature, 466, 226228, https://doi.org/10.1038/nature09213, 2010.

Ortega, P., Lehner, F., Swingedouw, D., Masson-Delmotte, V., Raible, C. C., Casado, M., and Yiou, P.: A model-tested North Atlantic Oscillation reconstruction for the past millennium, Nature, 523, 71-74, https://doi.org/10.1038/nature14518, 2015.

Pabortsava, K., Lampitt, R. S., Benson, J., Crowe, C., McLachlan, R., Le Moigne, F. A. C., Mark Moore, C., Pebody, C., Provost, P., Rees, A. P., Tilstone, G. H., and Woodward, E. M. S.: Carbon sequestration in the deep Atlantic enhanced by Saharan dust, Nat. Geosci., 10, 189-194, https://doi.org/10.1038/ngeo2899, 2017.

Pey, J., Querol, X., Alastuey, A., Forastiere, F., and Stafoggia, M.: African dust outbreaks over the Mediterranean Basin during 2001-2011: $\mathrm{PM}_{10}$ concentrations, phenomenology and trends, and its relation with synoptic and mesoscale meteorology, Atmos. Chem. Phys., 13, 1395-1410, https://doi.org/10.5194/acp13-1395-2013, 2013.

Prospero, J. M.: Environmental characterization of global sources of atmospheric soil dust identified with the NIMBUS 7 Total Ozone Mapping Spectrometer (TOMS) absorbing aerosol product, Rev. Geophys., 40, 1-31, https://doi.org/10.1029/2000RG000095, 2002.

Reimer, P. J., Bard, E., Bayliss, A., Beck, J. W., Blackwell, P. G., Ramsey, C. B., Buck, C. E., Cheng, H., Edwards, R. L., Friedrich, M., Grootes, P. M., Guilderson, T. P., Haflidason, H.,
Hajdas, I., Hatté, C., Heaton, T. J., Hoffmann, D. L., Hogg, A. G., Hughen, K. A., Kaiser, K. F., Kromer, B., Manning, S. W., Niu, M., Reimer, R. W., Richards, D. A., Scott, E. M., Southon, J. R., Staff, R. A., Turney, C. S. M., and van der Plicht, J.: IntCal13 and Marine13 Radiocarbon Age Calibration Curves 0-50 000 years cal BP, Radiocarbon, 55, 1869-1887, https://doi.org/10.2458/azu_js_rc.55.16947, 2013.

Reyss, J.-L., Schmidt, S., Legeleux, F., and Bonté, P.: Large, low background well-type detectors for measurements of environmental radioactivity, Nuclear Instruments and Methods in Physics Research Section A: Accelerators, Spectrometers, P. Soc Photo-Opt. Ins., 357, 391-397, https://doi.org/10.1016/01689002(95)00021-6, 1995.

Richter, T. O., van der Gaast, S., Koster, B., Vaars, A., Gieles, R., de Stigter, H. C., De Haas, H., and van Weering, T. C. E.: The Avaatech XRF Core Scanner: technical description and applications to NE Atlantic sediments, Geological Society, London, Special Publications, 267(1), 39-50, https://doi.org/10.1144/GSL.SP.2006.267.01.03, 2006.

Roche, B. and Loÿe-Pilot, M. D.: Eutrophisation récente d'un lac de montagne sans occupation humaine (lac de Bastani, Corset: Conséquence d'agents atmosphériques, Revue des sciences de l'eau, 2, 681-707, https://doi.org/10.7202/705049ar, 1989.

Rodrigo-Gámiz, M., Martínez-Ruiz, F., Jiménez-Espejo, F. J., Gallego-Torres, D., Nieto-Moreno, V., Romero, O., and Ariztegui, D.: Impact of climate variability in the western Mediterranean during the last 20000 years: oceanic and atmospheric responses, Quat. Sci. Rev., 30, 2018-2034, https://doi.org/10.1016/j.quascirev.2011.05.011, 2011.

Rosén, P., Vogel, H., Cunningham, L., Reuss, N., Conley, D. J., and Persson, P.: Fourier transform infrared spectroscopy, a new method for rapid determination of total organic and inorganic carbon and biogenic silica concentration in lake sediments, J. Paleolim., 43, 247-259, https://doi.org/10.1007/s10933-009-93294, 2010.

Rosenfeld, D., Lohmann, U., Raga, G. B., O’Dowd, C. D., Kulmala, M., Fuzzi, S., Reissell, A., and Andreae, M. O.: Flood or Drought: How Do Aerosols Affect Precipitation?, Science, 321, 1309-1313, https://doi.org/10.1126/science.1160606, 2008.

Sabatier, P., Dezileau, L., Briqueu, L., Colin, C. and Siani, G.: Clay minerals and geochemistry record from northwest Mediterranean coastal lagoon sequence: Implications for paleostorm reconstruction, Sedimentary Geology, 228(3-4), 205217, https://doi.org/10.1016/j.sedgeo.2010.04.012, 2010.

Sabatier, P., Dezileau, L., Colin, C., Briqueu, L., Bouchette, F., Martinez, P., Siani, G., Raynal, O., and Von Grafenstein, U.: 7000 years of paleostorm activity in the NW Mediterranean Sea in response to Holocene climate events, Quat. Res., 77, 1-11, https://doi.org/10.1016/j.yqres.2011.09.002, 2012.

Sabatier, P., Wilhelm, B., Ficetola Gentile, F., Moiroux, F., Poulenard, J., Develle, A.-L., Bichet, A., Chen, W., Pignol, C., Reyss, J.-L., Gielly, L., Bajard, M., Perrette, Y., Malet, E., Taberlet, P., and Arnaud, F.: $6 \mathrm{kyr}$ record of flood frequency and intensity in the western Mediterranean Alps - Interplay of solar and temperature forcing, Quat. Sci. Rev., 170, 121-135, https://doi.org/10.1016/j.quascirev.2017.06.019, 2017.

Scheuvens, D., Schütz, L., Kandler, K., Ebert, M., and Weinbruch, S.: Bulk composition of northern African dust and its 
source sediments - A compilation, Earth Sci. Rev., 116, 170194, https://doi.org/10.1016/j.earscirev.2012.08.005, 2013.

Shao, Y., Wyrwoll, K.-H., Chappell, A., Huang, J., Lin, Z., McTainsh, G. H., Mikami, M., Tanaka, T. Y., Wang, X., and Yoon, S.: Dust cycle: An emerging core theme in Earth system science, Aeolian Res., 2, 181-204, https://doi.org/10.1016/j.aeolia.2011.02.001, 2011.

Souza, P. and Cavalcanti, I. F. A.: Atmospheric centres of action associated with the Atlantic ITCZ position, Int. J. Climatol., 29, 2091-2105, https://doi.org/10.1002/joc.1823, 2009.

Steinhilber, F., Abreu, J. A., Beer, J., Brunner, I., Christl, M., Fischer, H., Heikkila, U., Kubik, P. W., Mann, M., McCracken, K. G., Miller, H., Miyahara, H., Oerter, H. and Wilhelms, F.: 9,400 years of cosmic radiation and solar activity from ice cores and tree rings, P. Natl. Acad. Sci. USA, 109, 5967-5971, https://doi.org/10.1073/pnas.1118965109, 2012.

Tomadin, L., Lenaz, R., Landuzzi, V., Mazzucotelli, A., and Vannucci, R.: Wind-blown dust over the central Mediterranean, Oceanol. Acta, 13-24, 1984.

Torrence, C. and Compo, G. P.: A Practical Guide to Wavelet Analysis, B. Am. Meteorol. Soc., 79, 61-78, https://doi.org/10.1175/15200477(1998)079<0061:APGTWA>2.0.CO;2, 1998.

van den Boogaart, K. G. and Tolosana-Delgado, R.: "Compositions": A unified $\mathrm{R}$ package to analyze compositional data, Comput. Geosci., 34, 320-338, https://doi.org/10.1016/j.cageo.2006.11.017, 2008.

Vannière, B., Magny, M., Joannin, S., Simonneau, A., Wirth, S. B., Hamann, Y., Chapron, E., Gilli, A., Desmet, M., and Anselmetti, F. S.: Orbital changes, variation in solar activity and increased anthropogenic activities: controls on the Holocene flood frequency in the Lake Ledro area, Northern Italy, Clim. Past, 9, 1193-1209, https://doi.org/10.5194/cp-9-1193-2

Vincent, J., Laurent, B., Losno, R., Bon Nguyen, E., Roullet, P., Sauvage, S., Chevaillier, S., Coddeville, P., Ouboulmane, N., di Sarra, A. G., Tovar-Sánchez, A., Sferlazzo, D., Massanet, A., Triquet, S., Morales Baquero, R., Fornier, M., Coursier, C., Desboeufs, K., Dulac, F., and Bergametti, G.: Variability of mineral dust deposition in the western Mediterranean basin and south-east of France, Atmos. Chem. Phys., 16, 8749-8766, https://doi.org/10.5194/acp-16-8749-2016, 2016.
Wang, W., Evan, A. T., Flamant, C., and Lavaysse, C.: On the decadal scale correlation between African dust and Sahel rainfall: The role of Saharan heat low-forced winds, Sci. Adv., 1, e1500646, https://doi.org/10.1126/sciadv.1500646, 2015.

Wang, W., Evan, A. T., Lavaysse, C., and Flamant, C.: The role the Saharan Heat Low plays in dust emission and transport during summertime in North Africa, Aeolian Res., 28, 1-12, https://doi.org/10.1016/j.aeolia.2017.07.001, 2017.

Wilhelm, B., Sabatier, P., and Arnaud, F.: Is a regional flood signal reproducible from lake sediments?, Sedimentology, 62, 11031117, https://doi.org/10.1111/sed.12180, 2015.

Wu, J., Liu, Z., Stuut, J.-B. W., Zhao, Y., Schirone, A., and de Lange, G. J.: North-African paleodrainage discharges to the central Mediterranean during the last 18000 years: A multiproxy characterization, Quat. Sci. Rev., 163, 95-113, https://doi.org/10.1016/j.quascirev.2017.03.015, 2017.

Yu, H., Chin, M., Yuan, T., Bian, H., Remer, L. A., Prospero, J. M., Omar, A., Winker, D., Yang, Y., Zhang, Y., Zhang, Z., and Zhao, C.: The fertilizing role of African dust in the Amazon rainforest: A first multiyear assessment based on data from Cloud-Aerosol Lidar and Infrared Pathfinder Satellite Observations: Dust Deposition in the Amazon Rainforest, Geophys. Res. Lett., 42, 19841991, https://doi.org/10.1002/2015GL063040, 2015.

Zhao, Y., Colin, C., Liu, Z., Bonneau, L., and Siani, G.: Climate forcing of terrigenous sediment input to the central Mediterranean Sea since the early Pleistocene, Palaeogeogr. Palaeoclim., 442, 23-35, https://doi.org/10.1016/j.palaeo.2015.11.006, 2016.

Zielhofer, C., von Suchodoletz, H., Fletcher, W. J., Schneider, B., Dietze, E., Schlegel, M., Schepanski, K., Weninger, B., Mischke, S., and Mikdad, A.: Millennial-scale fluctuations in Saharan dust supply across the decline of the African Humid Period, Quat. Sci. Rev., 171, 119-135, https://doi.org/10.1016/j.quascirev.2017.07.010, 2017. 